Article

\title{
Design, Synthesis and Biological Evaluation of Nitrate Derivatives of Sauropunol A and B as Potent Vasodilatory Agents
}

\author{
Lu Lu ${ }^{1}$, Xuemin Rao ${ }^{1}$, Rigang Cong ${ }^{2}$, Chenxi Zhang ${ }^{1}$, Zhimei Wang ${ }^{1}$, Jinyi Xu ${ }^{1}$, \\ Genzoh Tanabe ${ }^{3}$ DD, Osamu Muraoka ${ }^{3}$, Xiaoming $\mathrm{Wu}^{1, *}$ and Weijia Xie ${ }^{1, *}$ \\ 1 State Key Laboratory of Natural Medicines and Department of Medicinal Chemistry, \\ China Pharmaceutical University, 24 Tong Jia Xiang, Nanjing 210009, China; 18851739997@163.com (L.L.); \\ raochzh@163.com (X.R.); zcxciscy@163.com (C.Z.); 15295772843@163.com (Z.W.); jinyixu@cpu.edu.cn (J.X.) \\ 2 National Certified Enterprise Technology Center, Disha Pharmaceutical Group Co., Ltd., \\ Weihai 264205, China; crg1981@126.com \\ 3 Faculty of Pharmacy, Kinki University, 3-4-1 Kowakae, Higashi-Osaka, Osaka 577-8502, Japan; \\ g-tanabe@phar.kindai.ac.jp (G.T.); muraoka@phar.kindai.ac.jp (O.M.) \\ * Correspondence: xmwu@cpu.edu.cn (X.W.); weijiaxie@cpu.edu.cn (W.X.); Tel.: +86-25-8327-1414
}

Received: 20 December 2018; Accepted: 28 January 2019; Published: 6 February 2019

\begin{abstract}
A group of nitrate derivatives of naturally occurring sauropunol A and B were designed and synthesized. Nitric oxide (NO) releasing capacity and vasodilatory capacity studies were performed to explore the structure-activity relationship of resulted nitrates. Biological evaluation of these compounds revealed that most of the synthesized mononitrate derivatives demonstrated superior releasing capacity than isosorbide mononitrate (ISMN), and 2MNS-6 even demonstrated stronger NO releasing capacity than isosorbide dinitrate (ISDN). Two dinitrates, DNS-1 and DNS-2, showed higher NO releasing capacity than ISDN. Evaluation of inhibitory activities to the contractions in mesenteric artery rings revealed that 2MNS-8 and DNS-2 showed stronger vasorelaxation activities than ISDN. High level of NO and soluble guanylyl cyclase (sGC) may be essential for the potent vasodilatory effect of DNS-2. The vasodilatory effects of DNS-2 may result from cellular signal transduction of NO-sGC-cGMP. DNS-2 was found to be the most potent sauropunol-derived nitrate vasodilatory agent for further pharmaceutical investigation against cardiovascular diseases.
\end{abstract}

Keywords: vasodilatory agents; NO releasing capacity; sauropunol A and B; NO donor; Sauropus rostratus

\section{Introduction}

Nitric oxide has long been considered as a critical cellular signaling molecule related to different chemical and biological responses within the human body [1-3]. Since NO is extensively involved in numerous physiological and pathological processes, the manipulation of its biosynthesis as well as the administration of NO-releasing agents has emerged to be an effective way for the treatment of various human diseases such as cardiovascular disorders [4], neurodegeneration [5,6], inflammation [7], cancer [8-11], microorganism infection [12,13] and some immune diseases [14,15]. As a common method for drug design, molecular hybridization was usually used to introduce NO-releasing part, also known as NO donor, into an existing chemical entity. The resulting hybrid compounds usually present: (i) increased bioactivities compared to the parent compounds; (ii) new biological activities which were not observed in the parent compounds; (iii) less side effects than parent compounds [16-20].

NO donors have been used for many years in treatment of various clinical indications such as angina pectoris and coronary disease. Organic nitrate vasodilators such as gluceryl trinitrate (GTN), pentaerythritol tetranitrate (PETN), ISDN and ISMN are the oldest and the most successfully used NO 
donors in clinical application (Figure 1) [21]. However, one of the limitations of these drugs based on low dose nitrates is that they cannot conquer angina, and only show vein diastolic functions [22]. Thus, design and discovery of new NO-releasing compounds with stronger activity seems to be necessary.

Sauropus rostratus is the only reported plant with promising therapeutic value in the genus Sauropus. It was used in traditional Chinese medicine to treat cough, constipation and bronchitis [23]. Previous reports revealed that aqueous and alcohol extracts of Sauropus rostratus exhibited potent biological activities, including antibacterial, anti-inflammatory, analgesic and free radical-scavenging effects [24-26]. However, the detailed pharmaceutical investigation such as structure identification, organic synthesis and biological evaluation of single constituents of Sauropus rostratus was limited until a group of 2-deoxy-3,6-anhydro hexofuranoside derivatives 1-4 (Figure 1) were identified and isolated from leaves of Sauropus rostratus in 2014 [27]. Anhydro sugars constitute a specific and distinctive category of carbohydrates with intriguing physical, chemical and biological properties and thus, have attracted considerable attention from different chemical and pharmaceutical researchers, including our group [28-30]. Based on our recently developed synthetic strategy to construct 3,6-anhydro monosaccharides [31], the four naturally occurring 2-deoxy-3,6-anhydro hexofuranoside analogs 1-4 were synthesized and named by us [32]. The subsequent in vivo biological evaluation revealed that one of these anhydro sugars, sauropunol B, exhibited anti-inflammatory activity which is comparable with that of indomethacin [32]. In the meantime, the backbone structure similarity between sauropunol A-D and ISDN as well as ISMN prompted us to introduce NO donors into their structures, aiming at discovering new nitric oxide-releasing compounds as potential vasodilatory agents. Thus, in this study, a group of nitrate derivatives of sauropunol A and B were designed and synthesized. The NO-releasing abilities of these compounds were then tested in vitro and the vasorelaxation activities of these compounds were evaluated using isolated rat mesenteric arterial rings to shed light on the potential pharmaceutical applications of these naturally derived compounds for cardiovascular diseases.

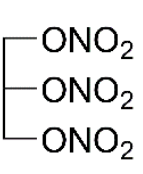

GTN

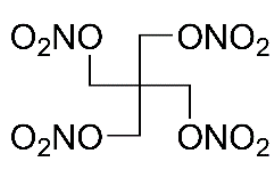

PETN

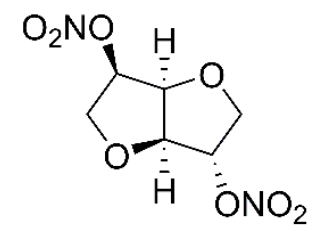

ISDN<smiles>O=[N+]([O-])[C@H]1CO[C@@H]2[C@@H](O)CO[C@H]12</smiles>

ISMN<smiles>CCOC1C[C@@H]2OC[C@H](O)C2O1</smiles>

sauropunol A (1)<smiles>CCCCOC1C[C@H]2OC[C@@H](O)C2O1</smiles>

sauropunol B (2)<smiles></smiles>

sauropunol C/D (3/4)

Figure 1. Structures of classical nitrate vasodilators and sauropunol A-D isolated from leaves of Sauropus rostratus.

\section{Results}

\subsection{Chemistry}

Natural products $\mathbf{1} / \mathbf{2}$ previously synthesized by our group [32] were directly treated with fuming nitric acid to give target 5-mononitrate derivatives 5MNS-1 and 5MNS-2 (Figure 2) [33]. In the other route, secondary alcohol 5 [32] was treated with fuming nitric acid to provide 5MNS-3. Deacetonization of 5MNS-3 and the subsequent glycosidation were conducted to give target 5MNS-4 and 5MNS-5 [34]. In the meantime, 5 was subjected to a Barton-McCombie reaction to give intermediate $6[35,36]$. 
In a similar manner, 6 was transferred to a pair of anomers $7 \mathbf{a} / 7 \mathbf{b}$, which were then directly subjected to nitration using fuming nitric acid to give target 5-deoxy-2-mononitrate derivatives $\mathbf{2 M N S - 1}$ and $\mathbf{2 M N S - 2 . ~}$

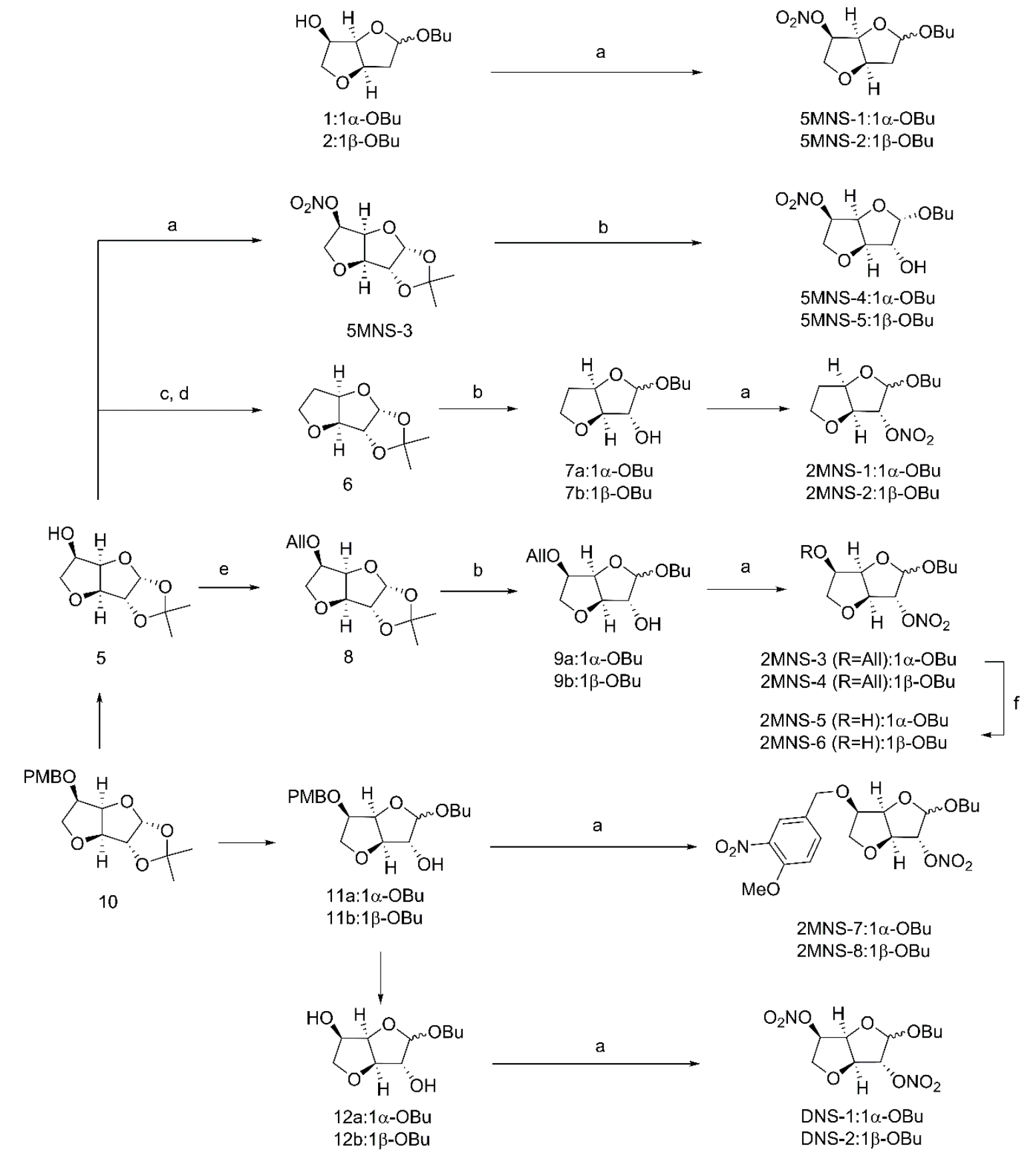

Figure 2. Preparation of nitrate derivatives. Reagents and conditions: (a) $\mathrm{HNO}_{3}, \mathrm{Ac}_{2} \mathrm{O}, 0^{\circ} \mathrm{C}$; (b) $p$-TSA, n-BuOH, rt; (c) PTC-Cl, DMAP, MeCN, rt; (d) AIBN, Bu $3 \mathrm{SnH}$, toluene, $130{ }^{\circ} \mathrm{C}$; (e) 3-bromopropene, $\mathrm{NaH}, \mathrm{DMF}, 0{ }^{\circ} \mathrm{C}-\mathrm{rt}$; (f) $10 \% \mathrm{Pd} / \mathrm{C}, p$-TSA, $\mathrm{MeOH}, 50{ }^{\circ} \mathrm{C}$.

Also starting from 5, the 5-hydroxyl group was first protected by an allyl group. The resulting intermediate 8 was transferred to a pair of anomers $9 a / 9 b$, which were then directly subjected to nitration using fuming nitric acid to give the target 2-mononitrate derivatives 2 MNS-3 and 2 MNS-4. Selective removal of the allylic protection of 2MNS-3 and 2MNS-4 provided another two 2-mononitrate derivatives 2MNS-5 and 2MNS-6. Interestingly, when we conducted nitration reactions upon the secondary alcohols $\mathbf{1 1 a / 1 1 b}$ [32], a nitro group was simultaneously attached on the phenyl ring moiety 
to give 2MNS-7 and 2MNS-8 as another two 2-mononitrate derivatives. Finally, diols 12a/12b [32] which upon nitration reaction were converted to the target 2,5-dinitrate derivatives DNS-1 and DNS-2.

\subsection{In Vitro Nitro Oxide Releasing Capacities}

In vitro NO releasing capacities of all synthesized NO donors were first measured by a Griess reaction [37-39]. As expected, all synthesized sauropunol-type nitrate derivatives showed NO releasing capacities in a time-dependent manner, as shown in Figure 3.

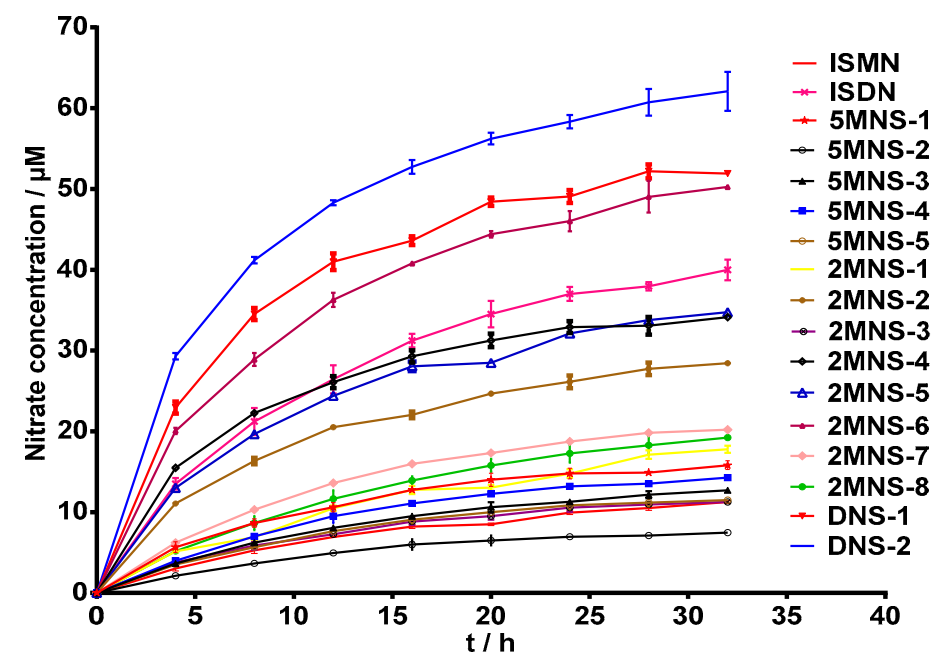

(a)

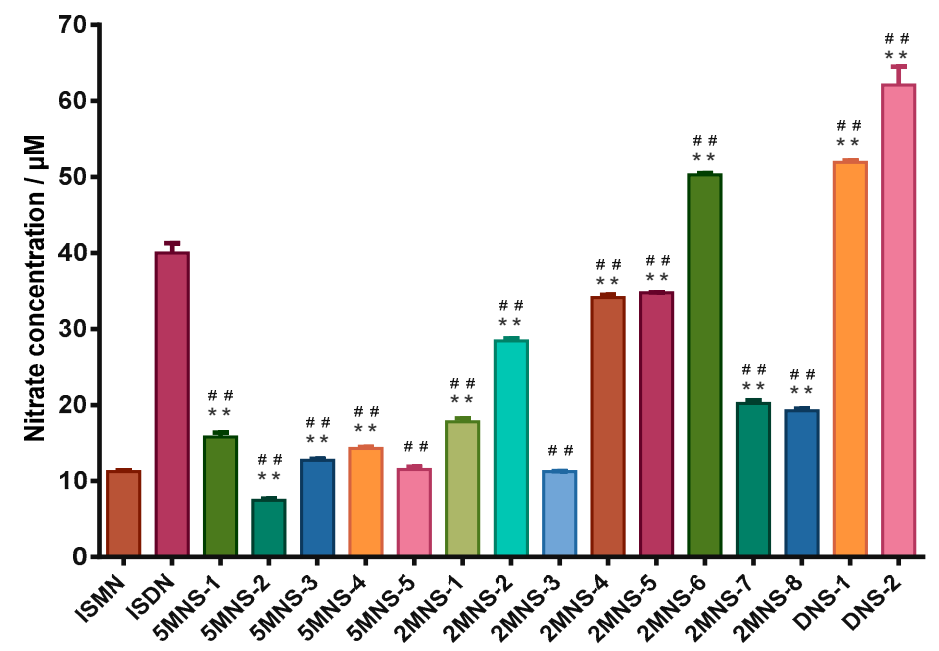

(b)

Figure 3. (a) level of nitrite for the test compounds $(100 \mu \mathrm{M})$ over duration of $32 \mathrm{~h}$ by Griess assay. (b) Nitrate concentration for the test compounds $(100 \mu \mathrm{M})$ at $32 \mathrm{~h}$ by Griess assay. Data are expressed as the mean $\pm \mathrm{SD}(n=6) .{ }^{*} p<0.05,{ }^{* *} p<0.01$ vs. ISMN, ${ }^{\#} p<0.05,{ }^{\# \#} p<0.01$ vs. ISDN.

In this evaluation, ISMN and ISDN were used as positive controls. To our delight, the two synthesized 2,5-dinitrate derivatives DNS-1 and DNS-2 showed higher NO releasing capacities than ISDN and most of synthesized mononitrate derivatives demonstrated superior NO releasing capacities than ISMN. The 2-mononitrate derivative 2MNS-6 even demonstrated superior NO releasing capacity 
than ISDN. The above evidence indicated that the presence of a carbohydrate structure (in the case of sauropunol-type nitrates) may further enhance the NO-releasing potency of the resulted nitrates when compared with ISMN and ISDN bearing similar bicyclic isosorbide skeletons. It was not surprising to find that 2,5-dinitrate derivatives DNS-1 and DNS-2 exhibited higher NO releasing quantities than all the other mononitrate derivatives $(p<0.05)$.

\subsection{Vasodilatory Effects on Isolated Rat Mesenteric Arterial Rings}

Vasodilation is the main mechanism of anti-angina agents. The reduction in blood pressure caused by a NO donor vasodilator leads to a decrease in myocardial oxygen consumption. In addition, the dilation of coronary arteries and reduction of cardiac preload lead to an increase of myocardial oxygen supply. Moreover, release of NO can protect ischemic cardiomyocytes and inhibit the formation of thrombus. The subtle blood pressure variation of peripheral resistance vessels can result in great blood pressure variation of mesenteric artery [40,41]. Thus, isolated mesenteric arterial rings were used to examine the vasodilatory effects of sauropunol-type nitrate derivatives. Contractions were induced by phenylephrine or $\mathrm{KCl}$ in mesenteric artery rings [42,43].

After precontraction of mesenteric artery rings with phenylephrine, nitrate derivatives were added to the bath when sustained contractions were obtained. The preliminary vasdilatory effects of nitrate derivatives on the mesenteric vascular rings in vitro were obtained and relaxation rates were showed in Table 1. The synthesized 2,5-dinitrate DNS-2 showed stronger vasorelaxation activities than ISDN. Some mononitrate derivatives such as 5MNS-1, 5MNS-2, 5MNS-3, 5MNS-4, 2MNS-3, 2MNS-4, 2MNS-7 and 2MNS-8 showed stronger vasorelaxation activities than ISMN. Even mononitrates such as 5MNS-1, 5MNS-3, 2MNS-4, 2MNS-8 showed stronger vasorelaxation activities than ISDN. 5MNS-2, 2MNS-3, 2MNS-7 and DNS-1 showed vasodilatory activities equivalent to that of ISDN. It can be easily observed that the synthesized 2,5-dinitrate derivative DNS-2 with the highest NO releasing capacity consistently showed the strongest vasodilatory effect.

Table 1. Inhibitory effects of nitrate derivatives $(30 \mu \mathrm{M})$ on the contractions induced by phenylephrine or $\mathrm{KCl}$ in mesenteric artery rings.

\begin{tabular}{|c|c|c|}
\hline Compounds & Relaxation $^{a}(\%)$ & Relaxation $^{b}(\%)$ \\
\hline ISMN & $8.01 \pm 3.59$ & $3.05 \pm 1.69$ \\
\hline ISDN & $30.21 \pm 2.55$ & $20.13 \pm 3.45$ \\
\hline 5MNS-1 & $58.13 \pm 3.01$ **\#\# & $24.21 \pm 2.79 * *$ \\
\hline 5MNS-2 & $30.21 \pm 2.90 * *$ & $15.15 \pm 3.01^{* *}$ \\
\hline 5MNS-3 & $45.38 \pm 3.51 * * \# \#$ & $16.09 \pm 2.01^{* *}$ \\
\hline 5MNS-4 & $20.11 \pm 4.73$ *\# & $11.86 \pm 3.56^{* \#}$ \\
\hline 5MNS-5 & $4.10 \pm 2.01^{\# \#}$ & $2.01 \pm 1.00^{\# \#}$ \\
\hline 2MNS-1 & $15.22 \pm 3.02^{\# \#}$ & $7.08 \pm 2.00^{\# \#}$ \\
\hline 2MNS-2 & $9.89 \pm 2.71^{\# \#}$ & $4.96 \pm 3.54 \#$ \\
\hline 2MNS-3 & $31.03 \pm 2.66^{* *}$ & $5.06 \pm 1.79 \#$ \\
\hline 2MNS-4 & $51.25 \pm 5.02 * * \#$ & $22.89 \pm 2.53^{* *}$ \\
\hline 2MNS-5 & $11.00 \pm 2.65 \#$ & $2.02 \pm 1.03^{\# \#}$ \\
\hline 2 MNS- 6 & $8.96 \pm 2.06^{\# \#}$ & $52.11 \pm 3.66^{* * \# \#}$ \\
\hline 2MNS-7 & $22.1 \pm 4.43^{*}$ & $86.27 \pm 2.37^{* * \# \#}$ \\
\hline 2MNS-8 & $67.56 \pm 3.86$ **\#\# & $85.17 \pm 4.54^{* * \# \#}$ \\
\hline DNS-1 & $29.21 \pm 3.66^{* *}$ & $80.87 \pm 5.31$ **\# \\
\hline DNS-2 & $81.98 \pm 6.10$ **\#\# & $85.22 \pm 6.01^{* * \# \#}$ \\
\hline
\end{tabular}

\footnotetext{
a Inhibitory effects of nitrate derivatives $(30 \mu \mathrm{M})$ on the contractions induced by phenylephrine $(1 \mu \mathrm{M})$ in mesenteric artery rings. ${ }^{b}$ Inhibitory effects of nitrate derivatives $(30 \mu \mathrm{M})$ on the contractions induced by of $\mathrm{KCl}(60 \mathrm{mM})$ in mesenteric artery rings. Data are expressed as the mean $\pm \mathrm{SD}(n=3) .{ }^{*} p<0.05,{ }^{* *} p<0.01$ vs. ISMN, ${ }^{\#} p<0.05$, \#\# $p<0.01$ vs. ISDN.
}

In the next biological evaluation, nitrate derivatives with relaxation rates of more than $30 \%$ were selected to investigate their dose-response relationships. Thus, all potent sauropunol-type nitrate 
derivatives showed vasodilatory capacities in a dose-dependent manner (see Supplementary Materials). As demonstrated in Table 2 left column, DNS-2 and 2MNS-8 were the most potent vasodilatory agent with $\mathrm{IC}_{50}$ of $6.02 \mu \mathrm{M}$, and $6.94 \mu \mathrm{M}$. 2-mononitrates $2 \mathrm{MNS}-3$ showed stronger vasodilatory potency than ISDN with $\mathrm{IC}_{50}$ of $12.08 \mu \mathrm{M}$. 2-mononitrates $2 \mathrm{MNS}-4$ showed almost the same vasodilatory potency compared to ISDN.

In the meantime, the vasodilatory capacities were also tested on the contractions induced by $\mathrm{KCl}$ in mesenteric artery rings. In a similar procedure, the preliminary vasdilatory effects of nitrate derivatives on the mesenteric vascular rings in vitro were obtained and the relaxation rates were showed in Table 1. Two synthesized 2,5-dinitrate derivatives DNS-1 and DNS-2 showed stronger potential vasorelaxation activities than ISDN. Most mononitrate derivatives such as 5MNS-1, 5MNS-2, 5MNS-3, 5MNS-4, 2MNS-4, 2MNS-6, 2MNS-7 and 2MNS-8 showed higher vasorelaxation activities than ISMN. Even mononitrates such as 2MNS-6, 2MNS-7 and 2MNS-8 showed more potent vasorelaxation activities than ISDN. It could be easily observed that 2MNS-7, 2MNS-8, DNS-1 and DNS-2 showed relatively higher vasodilatory effects.

Similarly, nitrate derivatives with relaxation rate more than $30 \%$ were selected to investigate their dose-response relationship. Thus, five potent sauropunol-type nitrate derivatives also showed vasodilatory capacities in a dose-dependent manner (see Supplementary Materials). IC $\mathrm{I}_{50}$ values were showed in Table 2 right column. In this examination, 2MNS-7 and 2MNS-8 exhibited the most potent vasodilatory activities with $\mathrm{IC}_{50}$ of $5.94 \mu \mathrm{M}$ and $5.52 \mu \mathrm{M}$. DNS-1 and DNS-2 displayed high vasodilatory potency with $\mathrm{IC}_{50}$ of $11.14 \mu \mathrm{M}$ and $10.03 \mu \mathrm{M}$ which were comparable with ISDN.

Table 2. $\mathrm{IC}_{50}$ of nitrate derivatives on the contractions induced by phenylephrine or $\mathrm{KCl}$ in mesenteric artery rings.

\begin{tabular}{|c|c|c|c|}
\hline Compounds & $\mathrm{IC}_{50}{ }^{\mathrm{a}}(\mu \mathrm{M})$ & Compounds & $\mathrm{IC}_{50} \mathrm{~b}(\mu \mathrm{M})$ \\
\hline ISMN & $42.30 \pm 3.52$ & ISMN & $35.34 \pm 2.52$ \\
\hline ISDN & $13.86 \pm 0.56$ & ISDN & $16.93 \pm 0.98$ \\
\hline 5MNS-1 & $24.25 \pm 0.50 * * \# \#$ & 2MNS-6 & $32.08 \pm 6.40^{\#}$ \\
\hline 5MNS-3 & $36.16 \pm 1.37 * \#$ & 2MNS-7 & $5.94 \pm 0.42 * * \#$ \\
\hline 2MNS-3 & $12.08 \pm 0.65^{* * \#}$ & 2MNS-8 & $5.52 \pm 0.47^{* * \# \#}$ \\
\hline 2MNS-4 & $13.75 \pm 1.00^{* *}$ & DNS-1 & $11.14 \pm 1.29 * * \#$ \\
\hline 2MNS-8 & $6.94 \pm 0.72$ **\#\# & DNS-2 & $10.03 \pm 0.72 * * \# \#$ \\
\hline DNS-2 & $6.02 \pm 0.40^{* * \# \#}$ & & \\
\hline
\end{tabular}

\footnotetext{
${ }^{\mathrm{a}} \mathrm{IC}_{50}$ of nitrate derivatives on the contractions induced by phenylephrine in mesenteric artery rings. ${ }^{\mathrm{b}} \mathrm{IC}_{50}$ of nitrate derivatives on the contractions induced by $\mathrm{KCl}$ in mesenteric artery rings. Data are expressed as the mean $\pm \mathrm{SD}$ $(n=3) .{ }^{*} p<0.05,{ }^{* *} p<0.01$ vs. ISMN, ${ }^{\#} p<0.05,{ }^{\# \#} p<0.01$ vs. ISDN.
}

\subsection{Effects of ODQ and PITO on Vasodilatory Effects of DNS-2}

In order to investigate whether DNS-2 display vasodilatory effect through cellular signal transduction of NO-sGC-cGMP, 2-phenyl-4,4,5,5-tetramethylimidazoline-1-oxyl 3-oxide (PTIO) and $1 \mathrm{H}-[1,2,4]$ oxadiazolo[4,3-a]quinoxalin-1-one (ODQ) were utilized in this experiment. PTIO is a stable radical scavenger for nitric oxide. It has significant inhibitory activity against $\mathrm{NO}$ biological actions without affecting NO synthase [44-46]. ODQ is a highly selective, irreversible, heme-site inhibitor of sGC $[47,48]$.

After pre-contraction of mesenteric artery rings with phenylephrine, the contracted rings were pretreated with or without PTIO, ODQ for $15 \mathrm{~min}$, and then treated with or without DNS-2. The vasdilatory effect of DNS-2 on the mesenteric vascular rings in vitro was obtained and relaxation rates were showed in Figure 4. In this biological evaluation, the relaxation rates of DNS-2 was reduced from $82.30 \pm 3.16 \%$ to $5.86 \pm 3.25 \%$ when NO scavenger PTIO was presented. The relaxation rate of DNS-2 was reduced to $4.67 \pm 2.57 \%$ when specific sGC inhibitor ODQ was presented. 


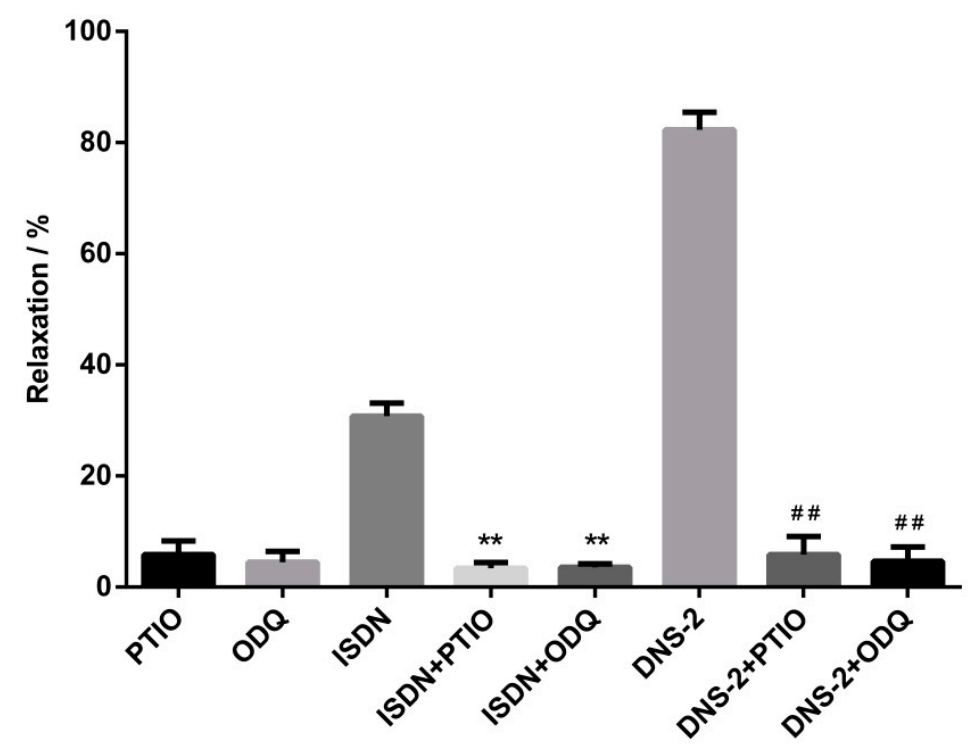

Figure 4. Inhibitory effects of DNS-2 $(30 \mu \mathrm{M})$ in the presence of PTIO $(100 \mu \mathrm{M})$ or ODQ $(10 \mu \mathrm{M})$ or PTIO $(100 \mu \mathrm{M})+$ ODQ $(10 \mu \mathrm{M})$ on the contractions induced by phenylephrine $(1 \mu \mathrm{M})$ in mesenteric artery rings. Data are expressed as the mean $\pm \mathrm{SD}(n=3) .{ }^{* *} p<0.01$ vs. ISDN, ${ }^{\# \#} p<0.01$ vs. DNS- 2 .

\section{Discussion}

In an in vitro nitro oxide releasing assay, some 2-mononitrate derivatives are more likely to release NO than 5-mononitrate derivatives that bearing similar skeletons as 2MNS-1, 2MNS-2, 2MNS-5 and 2MNS-6 showed stronger NO releasing capacities than 5MNS-1, 5MNS-2, 5MNS-4 and 5MNS-5 $(p<0.05)$. DNS- 2 displayed stronger NO releasing capacity than DNS-1, indicating that the $\beta$-anomer rather than the $\alpha$-anomer of 2,5 -dinitrate derivatives can more easily release $\mathrm{NO}(p<0.05)$. The same phenomenon was also observed for 2-mononitrate derivatives $(p<0.05)$. On the other hand, the reverse situation was encountered in the case of 5-mononitrate derivatives, as the $\alpha$-anomers $\mathbf{5 M N S}-1$ and 5MNS-4 showed greater NO releasing abilities than their $\beta$-counterparts 5 MNS- 2 and 5 MNS-5, respectively $(p<0.05)$. The performance of 5 MNS-4, 5 MNS-5, 2 MNS- 5 and 2 MNS- 6 indicating that 2-mononitrates other than 5 -mononitrates more easily release $\mathrm{NO}(p<0.05)$.

In the study of inhibitory effects on the contractions induced by phenylephrine in mesenteric artery rings, anomeric stereochemistry also played an important role in vasodilatory activities of each compounds. As for 2,5-dinitrates, the $\beta$-anomer DNS-2 showed greater vasodilatory effect than its $\alpha$-counterpart DNS-1 $(p<0.05)$. Similarly, the $\beta$-anomers of 2 -mononitrates showed greater or almost equal vasodilatory effects than their $\alpha$-counterparts. In the case of 5-mononitrates, 5MNS-1 and 5MNS-4 displayed stronger vasodilatory effects than 5MNS- 2 and 5MNS- 5 indicating that $\alpha$-anomers rather than $\beta$-anomers of 5 -mononitrates tend to possess stronger vasodilatory effects $(p<0.05)$. The above findings concerning the effects of anomeric stereochemistry on bioactivities were consistent with those obtained in previous $\mathrm{NO}$ releasing experiments. In addition, there is an interesting phenomenon in case of 2-mononitrate derivatives that compounds 2MNS-3, 2MNS-4, 2MNS-7 and 2MNS-8 possessing allyl groups or $p$-methoxybenzyl groups showed stronger vasodilatory effects than compounds 2MNS-1, 2MNS-2, 2MNS-5 and 2MNS-6 $(p<0.05)$ indicating that sterically hindered substitution at $5-\mathrm{C}$ position may play a positive role to increase vasodilatory effects.

In the study of inhibitory effects on the contractions induced by $\mathrm{KCl}$ in mesenteric artery rings, similar structure-activity relationship of 2-mononitrate and 5-mononitrate derivatives could be concluded for compared with those in former studies. In addition, there is an interesting phenomenon in the case of 2-mononitrate derivatives that 2MNS-7 and 2MNS-8 possessing $p$-methoxybenzyl groups showed unexpectedly potent vasodilatory effects in this test, comparable with those of DNS-1 and DNS-2 $(p>0.05)$. 
In the study to verify the contributions of NO and sGC on the vasodilatoy effect of DNS-2, the results showed that treatment with PTIO or ODQ did not affect contracted mesenteric artery rings whereas the introduction of DNS-2 alone remarkably vasodilated pre-contracted mesenteric artery rings. In sharp contrast, pretreatment with PTIO or ODQ significantly disminished the vasodilatory effect of DNS-2. The results indicated that the high level of NO and sGC may be essential for the potent vasodilatory effect of DNS-2.

In addition, compounds 2MNS-7 and 2MNS-8 which exhibited unexpected high vasodilatory effects produced relatively lower levels of NO. It is known that in vivo NO production from organic nitrates involves both enzymatic and nonenzymatic mechanisms. In particular, for organic nitrate esters (such as ISDN, ISMN, and GTN) mechanisms involving cytochrome P450 enzymes and glutathione S-transferase has been postulated [41]. Thus, further mechanistic studies rather than preliminary nitric oxide releasing assays on compounds 2MNS-7 and 2MNS-8 will be necessary in our next investigation. Among all nitrate derivatives, DNS-2 showed higher NO releasing capacity and stronger vasodilatory effects against contractions induced by both phenylephrine and $\mathrm{KCl}$ in mesenteric artery rings, indication DNS-2 was the most ideal sauropunol-derived nitrate against cardiovascular diseases.

\section{Materials and Methods}

\subsection{General Information}

Flash column chromatography purifications (medium pressure liquid chromatography) were carried out using silica gel 60 (200-400 mesh, Huanghai, Yantai, PR China). NMR spectra were collected on an AV-300 spectrometer $\left(300 \mathrm{MHz}{ }^{1} \mathrm{H}, 75 \mathrm{MHz}{ }^{13} \mathrm{C}\right.$, Bruker Corp., Karlsruhe, Germany) using $\mathrm{CDCl}_{3}$ as solvent. ${ }^{1} \mathrm{H}-\mathrm{NMR}$ chemical shifts are recorded in parts per million (ppm, $\delta$ ) relative to tetramethylsilane $(\delta 0.00 \mathrm{ppm})$ with the solvent resonance as an internal standard $\left(\mathrm{CDCl}_{3} \delta 7.26 \mathrm{ppm}\right)$. ${ }^{13} \mathrm{C}-\mathrm{NMR}$ chemical shifts are reported in ppm with the solvent peak $\left(\mathrm{CDCl}_{3} \delta 77.0 \mathrm{ppm}\right)$ as the internal standard. Coupling constants $(J)$ are given in Hz. Low- and High Resolution Mass measurements was performed on a QTOF 6520 mass spectrometer (Agilent Technologies China, Beijing, China) with electron spray ionization (ESI) as the ion source. Optical rotations were determined with a DIP-370 digital polarimeter (JASCO, Shanghai, PR China). Column chromatography was effected over Silysia silica gel BW-200 (Fuji, Japan). The IR spectra were measured on an Impact 410 Fourier transform infrared spectrometer (Nicolet, Guangzhou, PR China).

\subsection{Chemistry}

\subsubsection{Synthesis of Butyl 2-deoxy-3,6-anhydro-5-O-nitro- $\alpha$-D-arabinohexofuranoside (5MNS-1)}

Fuming nitric acid $(0.5 \mathrm{~mL})$ was added to acetic anhydride $(2 \mathrm{~mL})$ at $0{ }^{\circ} \mathrm{C}$. After stirring for $10 \mathrm{~min}$, the solution of $\mathbf{1}(200 \mathrm{mg}, 0.99 \mathrm{mmol})$ in $\mathrm{Ac}_{2} \mathrm{O}(2 \mathrm{~mL})$ was added into the acetic anhydride solution of fuming nitric acid. The mixture was stirred at $0{ }^{\circ} \mathrm{C}$ for $15 \mathrm{~min}$ and then poured into ice-water and extracted with EtOAc. The organic layer was washed with brine, dried with $\mathrm{Na}_{2} \mathrm{SO}_{4}$ and then concentrated under reduced pressure to give a crude product, which on column chromatography (hexane/EtOAc:20:1) gave 5MNS-1 $(250 \mathrm{mg}, 80 \%)$ as a colorless oil. $[\alpha]_{\mathrm{D}}{ }^{25}=+92.45(\mathrm{c}=0.11$ in $\mathrm{CHCl}_{3}$ ); IR (neat, $\mathrm{cm}^{-1}$ ): 3440, 3132, 2961, 2874, 2361, 1643, 1613, 1454, 1400, 1282, 1137, 1119, 1075, $1004,955,861,753,619,568,537,516 ;{ }^{1} \mathrm{H}-\mathrm{NMR}\left(\mathrm{CDCl}_{3}\right) \delta 5.41-5.15(\mathrm{~m}, 2 \mathrm{H}), 5.01-4.70(\mathrm{~m}, 2 \mathrm{H}), 3.95$ $(\mathrm{dd}, J=5.4,2.7 \mathrm{~Hz}, 2 \mathrm{H}), 3.78-3.52(\mathrm{~m}, 1 \mathrm{H}), 3.42-3.38(\mathrm{~m}, 1 \mathrm{H}), 2.24-2.12(\mathrm{~m}, 2 \mathrm{H}), 1.66-1.48(\mathrm{~m}, 2 \mathrm{H}), 1.34$ $(\mathrm{q}, J=7.4 \mathrm{~Hz}, 2 \mathrm{H}), 0.91(\mathrm{t}, J=7.3 \mathrm{~Hz}, 3 \mathrm{H}) ;{ }^{13} \mathrm{C}-\mathrm{NMR}\left(\mathrm{CDCl}_{3}\right) \delta$ 106.2, 82.2, 80.2, 79.2, 67.9, 67.2, 39.2, 31.1, 18.7, 13.3. HR-ESIMS $m / z[\mathrm{M}+\mathrm{H}]^{+}$: calcd for $\mathrm{C}_{10} \mathrm{H}_{18} \mathrm{NO}_{6}: 248.1056$; found:248.1058.

\subsubsection{Synthesis of Butyl 2-deoxy-3,6-anhydro-5-O-nitro- $\beta$-D-arabinohexofuranoside (5MNS-2)}

Fuming nitric acid $(0.5 \mathrm{~mL})$ was added to acetic anhydride $(2 \mathrm{~mL})$ at $0{ }^{\circ} \mathrm{C}$. After stirring for $10 \mathrm{~min}$, the solution of $2(200 \mathrm{mg}, 0.99 \mathrm{mmol})$ in $\mathrm{Ac}_{2} \mathrm{O}(2 \mathrm{~mL})$ was added into the acetic anhydride solution 
of fuming nitric acid. The mixture was stirred at $0{ }^{\circ} \mathrm{C}$ for $15 \mathrm{~min}$ and then poured into ice-water and extracted with EtOAc. The organic layer was washed with brine, dried with $\mathrm{Na}_{2} \mathrm{SO}_{4}$ and then concentrated under reduced pressure to give a crude product, which on column chromatography (hexane/EtOAc:20:1) gave 5MNS-2 $(250 \mathrm{mg}, 80 \%)$ as a colorless oil. $[\alpha]_{\mathrm{D}}{ }^{25}=+58.27\left(\mathrm{c}=0.16\right.$ in $\left.\mathrm{CHCl}_{3}\right)$; IR (neat, $\mathrm{cm}^{-1}$ ): 3440, 3132, 2962, 1639, 1454, 1400, 1282, 1251, 1137, 1121, 1071, 1036, 999, 955, 863, 619, 537,$517 ;{ }^{1} \mathrm{H}-\mathrm{NMR}\left(\mathrm{CDCl}_{3}\right): \delta 5.29-5.10(\mathrm{~m}, 2 \mathrm{H}), 4.90(\mathrm{t}, J=5.5 \mathrm{~Hz}, 1 \mathrm{H}), 4.85-4.77(\mathrm{~m}, 1 \mathrm{H}), 4.20-4.10$ $(\mathrm{m}, 1 \mathrm{H}), 4.08-3.99(\mathrm{~m}, 1 \mathrm{H}), 3.86-3.75(\mathrm{~m}, 1 \mathrm{H}), 3.42-3.30(\mathrm{~m}, 1 \mathrm{H}), 2.27-2.12(\mathrm{~m}, 2 \mathrm{H}), 1.62-1.54(\mathrm{~m}, 2 \mathrm{H})$, 1.46-1.33 (m, 2H), $0.93(\mathrm{t}, J=7.3 \mathrm{~Hz}, 3 \mathrm{H}) ;{ }^{13} \mathrm{C}-\mathrm{NMR}\left(\mathrm{CDCl}_{3}\right): \delta 105.7,83.0,81.2,80.7,68.2,66.5,41.0$, 31.5, 19.4, 13.9. HR-ESIMS $m / z[\mathrm{M}+\mathrm{H}]^{+}$: calcd for $\mathrm{C}_{10} \mathrm{H}_{18} \mathrm{NO}_{6}$ : 248.1056; found:248.1056.

\subsubsection{Synthesis of 1,2-O-Isopropylidene-3,6-anhydro-5-O-nitro- $\alpha$-D-glucofuranoside (5MNS-3)}

Fuming nitric acid $(0.5 \mathrm{~mL})$ was added to acetic anhydride $(2 \mathrm{~mL})$ at $0{ }^{\circ} \mathrm{C}$. After stirring for $10 \mathrm{~min}$, the solution of $5(200 \mathrm{mg}, 0.99 \mathrm{mmol})$ in $\mathrm{Ac}_{2} \mathrm{O}(2 \mathrm{~mL})$ was added into the acetic anhydride solution of fuming nitric acid. The mixture was stirred at $0{ }^{\circ} \mathrm{C}$ for $15 \mathrm{~min}$ and then poured into ice-water and extracted with EtOAc. The organic layer was washed with brine, dried with $\mathrm{Na}_{2} \mathrm{SO}_{4}$ and then concentrated under reduced pressure to give a crude product, which on column chromatography (hexane/EtOAc: $20: 1)$ gave 5MNS-3 $(250 \mathrm{mg}, 80 \%)$ as a colorless oil. $[\alpha]_{\mathrm{D}}{ }^{25}=+54.17(\mathrm{c}=0.15 \mathrm{in}$ $\mathrm{CHCl}_{3}$ ); IR (neat, $\mathrm{cm}^{-1}$ ): 3003, 2944, 2891, 1641, 1410, 1385, 1375, 1283, 1233, 1204, 1163, 1125, 1096, $1069,1008,904,894,863,844,830,593,539 ;{ }^{1} \mathrm{H}-\mathrm{NMR}\left(\mathrm{CDCl}_{3}\right) \delta 5.96(\mathrm{~d}, J=3.5 \mathrm{~Hz}, 1 \mathrm{H}), 5.35-5.26$ $(\mathrm{m}, 1 \mathrm{H}), 5.09(\mathrm{t}, J=4.4 \mathrm{~Hz}, 1 \mathrm{H}), 4.64(\mathrm{~d}, J=3.5 \mathrm{~Hz}, 1 \mathrm{H}), 4.57(\mathrm{~d}, J=4.2 \mathrm{~Hz}, 1 \mathrm{H}), 4.02(\mathrm{dd}, J=10.2,6.3 \mathrm{~Hz}$, $1 \mathrm{H}), 3.93(\mathrm{dd}, J=10.2,5.2 \mathrm{~Hz}, 1 \mathrm{H}), 1.50(\mathrm{~s}, 3 \mathrm{H}), 1.35(\mathrm{~s}, 3 \mathrm{H}) .{ }^{13} \mathrm{C}-\mathrm{NMR}\left(\mathrm{CDCl}_{3}\right) \delta 113.2,107.5,85.8,84.2$, 81.1, 80.7, 68.3, 27.5, 26.7.h-ESIMS $m / z[\mathrm{M}+\mathrm{H}]^{+}$: calcd for $\mathrm{C}_{9} \mathrm{H}_{14} \mathrm{NO}_{7}$ : 248.0692; found: 248.0694 .

\subsubsection{Synthesis of Butyl 3,6-anhydro-5-O-nitro- $\alpha$-D-glucofuranoside (5MNS-4) and Butyl} 3,6-anhydro-5-O-nitro- $\beta$-D-glucofuranoside (5MNS-5)

To a solution of 5MNS-3 $(200 \mathrm{mg}, 0.81 \mathrm{mmol})$ in $n-\mathrm{BuOH}(7 \mathrm{~mL})$ was added $p-\mathrm{TSA} \cdot \mathrm{H}_{2} \mathrm{O}(0.6 \mathrm{~g})$ at room temperature. After being stirred for $48 \mathrm{~h}$ at room temperature, the reaction mixture was concentrated under reduced pressure to give a colorless residue, which was then subjected to column chromatography (hexane/EtOAc:8/1 $\rightarrow$ hexane/EtOAc:5/1) to give compounds 5MNS-4 (35 mg, 16\%) and 5MNS-5 (110 mg, 52\%) as colorless oils. 5MNS-4: $[\alpha]_{\mathrm{D}}{ }^{25}=+92.28\left(\mathrm{c}=0.14\right.$ in $\left.\mathrm{CHCl}_{3}\right)$; IR (neat, $\mathrm{cm}^{-1}$ ): 3441, 3132, 2962, 2874, 1642, 1604, 1454, 1401, 1282, 1138, 1119, 1070, 1003, 955, 862, 615, 568, 535, 516; ${ }^{1} \mathrm{H}-\mathrm{NMR}\left(\mathrm{CDCl}_{3}\right): \delta 5.29-5.18(\mathrm{~m}, 1 \mathrm{H}), 5.18-5.11(\mathrm{~m}, 1 \mathrm{H}), 4.93(\mathrm{t}, J=5.4 \mathrm{~Hz}, 1 \mathrm{H}), 4.59-4.43$ $(\mathrm{m}, 1 \mathrm{H}), 4.19-4.07(\mathrm{~m}, 1 \mathrm{H}), 4.08-3.88(\mathrm{~m}, 2 \mathrm{H}), 3.84-3.73(\mathrm{~m}, 1 \mathrm{H}), 3.59-3.48(\mathrm{~m}, 1 \mathrm{H}), 2.73(\mathrm{~d}, J=6.3 \mathrm{~Hz}$, 1H), 1.69-1.51 (m, 2H), 1.43-1.28 (m, 2H), $0.91(\mathrm{t}, J=7.3 \mathrm{~Hz}, 3 \mathrm{H}) .{ }^{13} \mathrm{C}-\mathrm{NMR}\left(\mathrm{CDCl}_{3}\right) \delta$ 104.4, 88.0, 80.2, 78.6, 76.2, 69.3, 68.1, 31.5, 19.1, 13.8. HR-ESIMS $m / z$ [M + H] ${ }^{+}$: calcd for $\mathrm{C}_{10} \mathrm{H}_{18} \mathrm{NO}_{7}$ : 264.1005; found: 264.1015. 5MNS-5: $[\alpha]_{\mathrm{D}}{ }^{25}=+92.28\left(\mathrm{c}=0.14\right.$ in $\left.\mathrm{CHCl}_{3}\right)$; IR (neat, $\left.\mathrm{cm}^{-1}\right)$ : 3430, 3132, 2963, 1640, 1614, 1454, 1401, 1282, 1120, 1069, 1004, 953, 861, 783, 751, 617, 537, 517; ${ }^{1} \mathrm{H}-\mathrm{NMR}\left(\mathrm{CDCl}_{3}\right): \delta 5.27-5.16$ $(\mathrm{m}, 1 \mathrm{H}), 5.14-5.05(\mathrm{~m}, 1 \mathrm{H}), 5.01(\mathrm{~s}, 1 \mathrm{H}), 4.52(\mathrm{~d}, J=5.2 \mathrm{~Hz}, 1 \mathrm{H}), 4.21(\mathrm{~s}, 1 \mathrm{H}), 4.12-3.98(\mathrm{~m}, 2 \mathrm{H}), 3.88-3.75$ (m, 1H), 3.44-3.31 (m, 1H), $2.83(\mathrm{~s}, 1 \mathrm{H}), 1.63-1.50(\mathrm{~m}, 2 \mathrm{H}), 1.45-1.30(\mathrm{~m}, 2 \mathrm{H}), 0.92(\mathrm{t}, J=7.3 \mathrm{~Hz}, 3 \mathrm{H})$. ${ }^{13} \mathrm{C}-\mathrm{NMR}\left(\mathrm{CDCl}_{3}\right) \delta 110.4,88.5,81.2,80.4,80.2,68.5,67.5,31.3,19.3,13.9$. HR-ESIMS $m / z[\mathrm{M}+\mathrm{H}]^{+}$: calcd for $\mathrm{C}_{10} \mathrm{H}_{18} \mathrm{NO}_{7}$ : 264.1005; found: 264.1010 .

4.2.5. Synthesis of Butyl 5-deoxy-3,6-anhydro- $\alpha$-D-glucofuranoside (7a) and Butyl 5-deoxy-3,6-anhydro- $\beta$-D-glucofuranoside (7b)

To a solution of $6(200 \mathrm{mg}, 1.08 \mathrm{mmol})$ in $n-\mathrm{BuOH}(7 \mathrm{~mL})$ was added $p-\mathrm{TSA} \cdot \mathrm{H}_{2} \mathrm{O}(0.6 \mathrm{~g})$ at room temperature. After being stirred for $48 \mathrm{~h}$ at room temperature, the reaction mixture was concentrated under reduced pressure to give a colorless residue, which was then subjected to column chromatography (hexane/EtOAc: $8 / 1 \rightarrow$ hexane/EtOAc:5/1) to give compounds 7 a (39 mg, 18\%) and $7 \mathbf{b}(107 \mathrm{mg}, 49 \%)$ as colorlessoils. $7 \mathrm{a}:[\alpha]_{\mathrm{D}}{ }^{25}=+117.62\left(\mathrm{c}=0.15\right.$ in $\left.\mathrm{CHCl}_{3}\right) ;{ }^{1} \mathrm{H}-\mathrm{NMR}\left(\mathrm{CDCl}_{3}\right) \delta 5.06$ $(\mathrm{d}, J=4.6 \mathrm{~Hz}, 1 \mathrm{H}), 4.78(\mathrm{t}, J=5.0 \mathrm{~Hz}, 1 \mathrm{H}), 4.40(\mathrm{dd}, J=4.8,2.4 \mathrm{~Hz}, 1 \mathrm{H}), 4.08(\mathrm{~s}, 1 \mathrm{H}), 3.94(\mathrm{td}, J=8.3$, 
$2.0 \mathrm{~Hz}, 1 \mathrm{H}), 3.87-3.66(\mathrm{~m}, 2 \mathrm{H}), 3.56-3.45(\mathrm{~m}, 1 \mathrm{H}), 2.75(\mathrm{~d}, J=7.9 \mathrm{~Hz}, 1 \mathrm{H}), 2.09-1.97(\mathrm{~m}, 1 \mathrm{H}), 1.94-1.80$ $(\mathrm{m}, 1 \mathrm{H}), 1.66-1.55(\mathrm{~m}, 2 \mathrm{H}), 1.47-1.32(\mathrm{~m}, 2 \mathrm{H}), 0.93(\mathrm{t}, J=7.3 \mathrm{~Hz}, 3 \mathrm{H}) .{ }^{13} \mathrm{C}-\mathrm{NMR}\left(\mathrm{CDCl}_{3}\right) \delta 102.3,88.4$, 80.4, 77.3, 67.7, 66.4, 32.6, 31.1, 18.8, 13.3. HR-ESIMS $m / z[\mathrm{M}+\mathrm{H}]^{+}$: calcd for $\mathrm{C}_{10} \mathrm{H}_{19} \mathrm{O}_{4}$ : 203.1205; found: 203.1205. 7b: $[\alpha]_{\mathrm{D}}{ }^{25}=+21.51\left(\mathrm{c}=0.10\right.$ in $\left.\mathrm{CHCl}_{3}\right) ;{ }^{1} \mathrm{H}-\mathrm{NMR}\left(\mathrm{CDCl}_{3}\right) \delta 5.00(\mathrm{t}, J=5.2 \mathrm{~Hz}, 1 \mathrm{H})$, $4.94(\mathrm{~s}, 1 \mathrm{H}), 4.36(\mathrm{~d}, J=4.8 \mathrm{~Hz}, 1 \mathrm{H}), 4.18(\mathrm{~s}, 1 \mathrm{H}), 4.08-3.96(\mathrm{~m}, 1 \mathrm{H}), 3.94-3.85(\mathrm{~m}, 1 \mathrm{H}), 3.74-3.64(\mathrm{~m}, 1 \mathrm{H})$, 3.45-3.34 (m, 1H), $2.65(\mathrm{~s}, 1 \mathrm{H}), 2.17-2.05(\mathrm{~m}, 1 \mathrm{H}), 2.05-1.88(\mathrm{~m}, 1 \mathrm{H}), 1.62-1.49(\mathrm{~m}, 2 \mathrm{H}), 1.41-1.31(\mathrm{~m}, 2 \mathrm{H})$, $0.91(\mathrm{t}, J=7.3 \mathrm{~Hz}, 3 \mathrm{H}) .{ }^{13} \mathrm{C}-\mathrm{NMR}\left(\mathrm{CDCl}_{3}\right) \delta 109.0,87.5,83.9,79.9,67.6,67.4,33.7,31.0,18.8,13.4$. HR-ESIMS $m / z$ [M $+\mathrm{H}]^{+}$: calcd for $\mathrm{C}_{10} \mathrm{H}_{19} \mathrm{O}_{4}$ : 203.1205; found: 203.1210 .

4.2.6. Synthesis of Butyl 5-deoxy3,6-anhydro-2-O-nitro- $\alpha$-D-glucofuranoside (2MNS-1) and Butyl 5-deoxy-3,6-anhydro-2-O-nitro- $\beta$-D-glucofuranoside (2MNS-2)

Fuming nitric acid $(0.5 \mathrm{~mL})$ was added to acetic anhydride $(2 \mathrm{~mL})$ at $0{ }^{\circ} \mathrm{C}$. After stirring for $10 \mathrm{~min}$, the solution of $7 \mathbf{a}(200 \mathrm{mg}, 0.99 \mathrm{mmol})$ in $\mathrm{Ac}_{2} \mathrm{O}(2 \mathrm{~mL})$ was added into the acetic anhydride solution of fuming nitric acid. The mixture was stirred at $0{ }^{\circ} \mathrm{C}$ for $15 \mathrm{~min}$ and then poured into ice-water and extracted with EtOAc. The organic layer was washed with brine, dried with $\mathrm{Na}_{2} \mathrm{SO}_{4}$ and then concentrated under reduced pressure to give a crude product, which on column chromatography (hexane/EtOAc:20:1) gave 2MNS-1 $(198 \mathrm{mg}, 81 \%)$ as a colorless oil. $[\alpha]_{\mathrm{D}}^{25}=+119.32(\mathrm{c}=0.09 \mathrm{in}$ $\mathrm{CHCl}_{3}$ ); IR (neat, $\mathrm{cm}^{-1}$ ): 3440, 3335, 3132, 2961, 2874, 1642, 1613, 1454, 1440, 1283, 1138, 1120, 1070, $1044,1018,954,857,825,624,537,516,427 .{ }^{1} \mathrm{H}-\mathrm{NMR}\left(\mathrm{CDCl}_{3}\right) \delta 5.45-5.19(\mathrm{~m}, 1 \mathrm{H}), 4.98-4.92(\mathrm{~m}, 1 \mathrm{H})$, $4.78(\mathrm{t}, J=5.3 \mathrm{~Hz}, 1 \mathrm{H}), 4.74-4.67(\mathrm{~m}, 1 \mathrm{H}), 4.01(\mathrm{t}, J=8.2 \mathrm{~Hz}, 1 \mathrm{H}), 3.86-3.67(\mathrm{~m}, 2 \mathrm{H}), 3.45-3.32(\mathrm{~m}, 1 \mathrm{H})$, $2.08(\mathrm{dd}, J=13.6,5.2 \mathrm{~Hz}, 1 \mathrm{H}), 1.99-1.83(\mathrm{~m}, 1 \mathrm{H}), 1.60-1.47(\mathrm{~m}, 2 \mathrm{H}), 1.38-1.27(\mathrm{~m}, 2 \mathrm{H}), 0.90(\mathrm{t}, J=7.3 \mathrm{~Hz}$, $3 \mathrm{H}) .{ }^{13} \mathrm{C}-\mathrm{NMR}\left(\mathrm{CDCl}_{3}\right) \delta 101.4,86.2,83.4,80.1,68.1,67.1,32.8,31.4,19.2,13.8$. HR-ESIMS $m / z[\mathrm{M}+\mathrm{H}]^{+}$: calcd for $\mathrm{C}_{10} \mathrm{H}_{18} \mathrm{NO}_{6}$ : 248.1056; found: 248.1056 .

In a similar manner, 2 MNS-2 (198 mg, $81 \%$ yield) was obtained as a colorless oil from $7 \mathbf{b}(200 \mathrm{mg}$, $0.99 \mathrm{mmol}) .[\alpha]_{\mathrm{D}}{ }^{25}=+37.10\left(\mathrm{c}=0.11\right.$ in $\mathrm{CHCl}_{3}$ ); IR (neat, $\left.\mathrm{cm}^{-1}\right)$ : 3441, 3132, 2962, 1648, 1616, 1454, 1400, 1302, 1270, 1120, 1091, 1071, 1030, 953, 843, 618, 537, 516. ${ }^{1} \mathrm{H}-\mathrm{NMR}\left(\mathrm{CDCl}_{3}\right) \delta 5.21(\mathrm{~s}, 1 \mathrm{H}), 5.05$ (s, 1H), 5.02-4.89 (m, 1H), $4.52(\mathrm{~d}, J=5.1 \mathrm{~Hz}, 1 \mathrm{H}), 4.16-4.03(\mathrm{~m}, 1 \mathrm{H}), 3.94(\mathrm{td}, J=8.2,2.5 \mathrm{~Hz}, 1 \mathrm{H})$, 3.77-3.66 (m, 1H), 3.49-3.37 (m, 1H), 2.16-1.95 (m, 2H), 1.63-1.51 (m, 2H), 1.42-1.31 (m, 2H), 0.92 $(\mathrm{t}, J=7.3 \mathrm{~Hz}, 3 \mathrm{H}) .{ }^{13} \mathrm{C}-\mathrm{NMR}\left(\mathrm{CDCl}_{3}\right) \delta 105.5,89.8,85.0,83.9,68.4,68.2,34.2,31.4,19.3,13.8$. HR-ESIMS $m / z[\mathrm{M}+\mathrm{H}]^{+}$: calcd for $\mathrm{C}_{10} \mathrm{H}_{18} \mathrm{NO}_{6}$ : 248.1056; found: 248.1059 .

\subsubsection{Synthesis of 1,2-O-Isopropylidene-3,6-anhydro-5-O-allyl- $\alpha$-D-glucofuranoside (8)}

To a mixture of sodium hydride ( $\mathrm{NaH}, 60 \%$ in liquid paraffin, $128 \mathrm{mg}, 3.2 \mathrm{mmol}$ ) and allyl bromide $(0.28 \mathrm{~mL}, 3.2 \mathrm{mmol})$ in dry DMF $(10 \mathrm{~mL})$ was added a solution of $5(303 \mathrm{mg}, 1.5 \mathrm{mmol})$ in dry DMF at $0{ }^{\circ} \mathrm{C}$. After stirring at $0{ }^{\circ} \mathrm{C}$ for $4 \mathrm{~h}$, the reaction was quenched by the addition of ice-water. The resulted solution was extracted with EtOAc. The combined extracts were washed with brine, and condensed under reduced pressure to give a yellow oil, which was then subjected to column chromatography (hexane/EtOAc:25/1), gave compound $8(345 \mathrm{mg}, 95 \%)$ as a pale yellow oil. $[\alpha]_{\mathrm{D}}{ }^{25}=+40.05(\mathrm{c}=0.13$ in $\mathrm{CHCl}_{3}$ ); IR (neat, $\mathrm{cm}^{-1}$ ): 3132, 2990, 2386, 2285, 1648, 1399, 1234, 1164, 1070, 1017, 930, 898, 858, 828, 548, 520; ${ }^{1} \mathrm{H}-\mathrm{NMR}\left(\mathrm{CDCl}_{3}\right) \delta 6.15-5.78(\mathrm{~m}, 2 \mathrm{H}), 5.43-5.17(\mathrm{~m}, 2 \mathrm{H}), 4.96-4.78(\mathrm{~m}, 1 \mathrm{H}), 4.58(\mathrm{t}, J=3.8 \mathrm{~Hz}, 1 \mathrm{H})$, $4.49(\mathrm{t}, J=3.7 \mathrm{~Hz}, 1 \mathrm{H}), 4.25-4.13(\mathrm{~m}, 1 \mathrm{H}), 4.13-3.89(\mathrm{~m}, 3 \mathrm{H}), 3.72-3.61(\mathrm{~m}, 1 \mathrm{H}), 1.50(\mathrm{~s}, 3 \mathrm{H}), 1.33(\mathrm{~s}, 3 \mathrm{H})$. ${ }^{13} \mathrm{C}-\mathrm{NMR}\left(\mathrm{CDCl}_{3}\right) \delta 134.3,118.0,112.3,107.2,85.6,85.1,80.7,78.9,71.6,69.5,27.3,26.7$. HR-ESIMS $\mathrm{m} / \mathrm{z}$ $[\mathrm{M}+\mathrm{H}]^{+}$: calcd for $\mathrm{C}_{12} \mathrm{H}_{19} \mathrm{O}_{5}: 243.1154$; found: 243.1150 .

4.2.8. Synthesis of Butyl 3,6-anhydro-5-O-allyl- $\alpha$-D-glucofuranoside (9a) and Butyl 3,6-anhydro-5-O-allyl- $\beta$-D-glucofuranoside (9b)

To a solution of $8(300 \mathrm{mg}, 1.16 \mathrm{mmol})$ in $n$ - $\mathrm{BuOH}(5 \mathrm{~mL})$ was added $p-\mathrm{TSA} \cdot \mathrm{H}_{2} \mathrm{O}(0.6 \mathrm{~g})$ at room temperature. After being stirred for $48 \mathrm{~h}$ at room temperature, the reaction mixture was concentrated under reduced pressure to give a colorless residue, which was then subjected to column chromatography (hexane/EtOAc:8/1 $\rightarrow$ hexane/EtOAc:5/1) to give compounds 9a (54 mg, 18\%) and 
9b $(180 \mathrm{mg}, 60 \%)$ as colorless oils. 9a: $[\alpha]_{\mathrm{D}}^{25}=+90.43\left(\mathrm{c}=0.16\right.$ in $\left.\mathrm{CHCl}_{3}\right)$; IR (neat, $\left.\mathrm{cm}^{-1}\right)$ : 3133, $2959,2873,2360,2342,1647,1458,1401,1269,1142,1064,1020,953,860,669,549 ;{ }^{1} \mathrm{H}-\mathrm{NMR}\left(\mathrm{CDCl}_{3}\right) \delta$ 6.03-5.85 (m, 1H), $5.31(\mathrm{dd}, J=17.0,1.9 \mathrm{~Hz}, 1 \mathrm{H}), 5.26-5.13(\mathrm{~m}, 2 \mathrm{H}), 4.63(\mathrm{t}, J=4.7 \mathrm{~Hz}, 1 \mathrm{H}), 4.50-4.41$ $(\mathrm{m}, 1 \mathrm{H}), 4.22-4.02(\mathrm{~m}, 3 \mathrm{H}), 4.01-3.90(\mathrm{~m}, 2 \mathrm{H}), 3.89-3.78(\mathrm{~m}, 1 \mathrm{H}), 3.63-3.49(\mathrm{~m}, 2 \mathrm{H}), 3.04(\mathrm{~d}, J=7.4 \mathrm{~Hz}$, 1H), $1.74-1.53(\mathrm{~m}, 2 \mathrm{H}), 1.38(\mathrm{q}, J=7.5 \mathrm{~Hz}, 2 \mathrm{H}), 0.93(\mathrm{t}, J=7.3 \mathrm{~Hz}, 3 \mathrm{H}) .{ }^{13} \mathrm{C}-\mathrm{NMR}\left(\mathrm{CDCl}_{3}\right) \delta 134.1$, 117.6, 103.1, 88.0, 77.9, 77.7, 77.2, 71.4, 68.1, 67.9, 31.2, 18.9, 13.5. HR-ESIMS $m / z[\mathrm{M}+\mathrm{H}]^{+}$: calcd for $\mathrm{C}_{13} \mathrm{H}_{23} \mathrm{O}_{5}:$ : 259.1467; found: 259.1465. 9b: $[\alpha]_{\mathrm{D}}^{25}=+8.19\left(\mathrm{c}=0.12\right.$ in $\mathrm{CHCl}_{3}$ ); IR (neat, $\left.\mathrm{cm}^{-1}\right)$ : 3449, 3130, 2960, 2936, 2872, 2382, 1648, 1459, 1400, 1315, 1268, 1116, 1085, 1018, 942, 888, 843, 787, 651, 595, 553, 450; ${ }^{1} \mathrm{H}-\mathrm{NMR}\left(\mathrm{CDCl}_{3}\right) \delta$ 6.03-5.85 (m, 1H), 5.44-5.26 (m, 1H), 5.25-5.16 (m, 1H), $5.02(\mathrm{~s}, 1 \mathrm{H}), 4.83$ $(\mathrm{t}, J=4.7 \mathrm{~Hz}, 1 \mathrm{H}), 4.43(\mathrm{~d}, J=4.7 \mathrm{~Hz}, 1 \mathrm{H}), 4.30-4.11(\mathrm{~m}, 2 \mathrm{H}), 4.08-3.90(\mathrm{~m}, 3 \mathrm{H}), 3.90-3.76(\mathrm{~m}, 2 \mathrm{H})$, $3.67(\mathrm{~d}, J=3.7 \mathrm{~Hz}, 1 \mathrm{H}), 3.44-3.31(\mathrm{~m}, 1 \mathrm{H}), 1.64-1.51(\mathrm{~m}, 2 \mathrm{H}), 1.41-1.30(\mathrm{~m}, 2 \mathrm{H}), 0.91(\mathrm{t}, J=7.3 \mathrm{~Hz}, 3 \mathrm{H})$. ${ }^{13} \mathrm{C}-\mathrm{NMR}\left(\mathrm{CDCl}_{3}\right) \delta 134.4,117.4,109.8,87.6,81.3,80.4,78.5,71.1,69.1,67.8,31.3,19.3,13.8$. HR-ESIMS $m / z[\mathrm{M}+\mathrm{H}]^{+}$: calcd for $\mathrm{C}_{13} \mathrm{H}_{23} \mathrm{O}_{5}: 259.1467$; found: 259.1469 .

\subsubsection{Synthesis of Butyl 3,6-anhydro-2-O-nitro-5-O-allyl- $\alpha$-D-glucofuranoside (2MNS-3) and Butyl} 3,6-anhydro-2-O-nitro-5-O-allyl- $\beta$-D-glucofuranoside (2MNS-4)

Fuming nitric acid $(0.25 \mathrm{~mL})$ was added to acetic anhydride $(1 \mathrm{~mL})$ at $0{ }^{\circ} \mathrm{C}$. After stirring for $10 \mathrm{~min}$, the solution of $9 \mathbf{a}(60 \mathrm{mg}, 0.23 \mathrm{mmol})$ in $\mathrm{Ac}_{2} \mathrm{O}(1 \mathrm{~mL})$ was added into the acetic anhydride solution of fuming nitric acid. The mixture was stirred at $0{ }^{\circ} \mathrm{C}$ for $15 \mathrm{~min}$ and then poured into ice-water and extracted with EtOAc. The organic layer was washed with brine, dried with $\mathrm{Na}_{2} \mathrm{SO}_{4}$ and then concentrated under reduced pressure to give a crude product, which on column chromatography (hexane/EtOAc:20:1) gave 2MNS-3 (56 mg, 80\%) as a colorless oil. $[\alpha]_{\mathrm{D}}{ }^{25}=+129.68\left(\mathrm{c}=0.11\right.$ in $\left.\mathrm{CHCl}_{3}\right)$; IR (neat, $\mathrm{cm}^{-1}$ ): 3441, 3335, 3131, 1660, 1640, 1612, 1454, 1400, 1282, 1138, 1121, 1070, 997, 955, 863, 619, 563, 538, 517; ${ }^{1} \mathrm{H}-\mathrm{NMR}\left(\mathrm{CDCl}_{3}\right) \delta 6.04-5.87(\mathrm{~m}, 1 \mathrm{H}), 5.46(\mathrm{~d}, J=4.2 \mathrm{~Hz}, 1 \mathrm{H}), 5.40-5.18(\mathrm{~m}, 2 \mathrm{H}), 5.07-4.99$ $(\mathrm{m}, 1 \mathrm{H}), 4.77-4.70(\mathrm{~m}, 1 \mathrm{H}), 4.68-4.55(\mathrm{~m}, 1 \mathrm{H}), 4.23-4.07(\mathrm{~m}, 2 \mathrm{H}), 4.07-3.95(\mathrm{~m}, 2 \mathrm{H}), 3.83-3.73(\mathrm{~m}, 1 \mathrm{H})$, 3.72-3.59 (m, 1H), 3.49-3.38 (m, 1H), 1.68-1.47 (m, 2H), 1.46-1.16 (m, 2H), $0.90(\mathrm{t}, J=7.3 \mathrm{~Hz}, 3 \mathrm{H})$. ${ }^{13} \mathrm{C}-\mathrm{NMR}\left(\mathrm{CDCl}_{3}\right) \delta 134.1,118.2,102.0,86.3,82.9,77.6,76.7,71.9,68.4,68.3,31.2,19.0,13.6$. HR-ESIMS $m / z[\mathrm{M}+\mathrm{H}]^{+}$: calcd for $\mathrm{C}_{13} \mathrm{H}_{22} \mathrm{NO}_{7}$ : 304.1318; found: 304.1321 .

In a similar manner, 2 MNS-4 (188 $\mathrm{mg}, 80 \%$ yield) was obtained as a colorless oil from $\mathbf{9 b}(200 \mathrm{mg}$, $0.77 \mathrm{mmol}) .[\alpha]_{\mathrm{D}}{ }^{25}=+24.87\left(\mathrm{c}=0.13\right.$ in $\mathrm{CHCl}_{3}$ ); IR (neat, $\left.\mathrm{cm}^{-1}\right): 3441,3132,1654,1613,1454,1400$, $1302,1270,1138,1119,1071,994,953,845,618,564,537,517 ;{ }^{1} \mathrm{H}-\mathrm{NMR}\left(\mathrm{CDCl}_{3}\right) \delta 6.02-5.85(\mathrm{~m}, 1 \mathrm{H})$, $5.34(\mathrm{q}, J=1.6 \mathrm{~Hz}, 1 \mathrm{H}), 5.26-5.18(\mathrm{~m}, 2 \mathrm{H}), 5.15(\mathrm{~s}, 1 \mathrm{H}), 4.81(\mathrm{t}, J=4.8 \mathrm{~Hz}, 1 \mathrm{H}), 4.62(\mathrm{~d}, J=5.1 \mathrm{~Hz}, 1 \mathrm{H})$, $4.25-4.13(\mathrm{~m}, 1 \mathrm{H}), 4.08-3.96(\mathrm{~m}, 3 \mathrm{H}), 3.95-3.84(\mathrm{~m}, 2 \mathrm{H}), 3.47-3.37(\mathrm{~m}, 1 \mathrm{H}), 1.65-1.53(\mathrm{~m}, 2 \mathrm{H}), 1.43-1.33$ $(\mathrm{m}, 2 \mathrm{H}), 0.92(\mathrm{t}, J=7.3 \mathrm{~Hz}, 3 \mathrm{H}) .{ }^{13} \mathrm{C}-\mathrm{NMR}\left(\mathrm{CDCl}_{3}\right) \delta 134.4,117.6,105.7,90.0,83.7,81.7,78.2,71.3,69.5$, 68.2, 31.2, 19.3, 13.9. HR-ESIMS $m / z$ [M + H] ${ }^{+}$: calcd for $\mathrm{C}_{13} \mathrm{H}_{22} \mathrm{NO}_{7}$ : 304.1318; found: 304.1320.

4.2.10. Synthesis of Butyl 3,6-anhydro-2-O-nitro- $\alpha$-D-glucofuranoside (2MNS-5) and Butyl 3,6-anhydro-2-O-nitro- $\beta$-D-glucofuranoside (2MNS-6)

To a solution of 2MNS-3 (56 mg, $0.19 \mathrm{mmol})$ in methanol $(5 \mathrm{~mL})$ was added $10 \% \mathrm{Pd}-\mathrm{C}(18 \mathrm{mg})$ at room temperature. After being stirred for $5 \mathrm{~h}$, The catalyst was filtered off and washed with methanol. The combined filtrate and the washings were condensed under reduced pressure to give a pale yellow oil, which was then subjected to column chromatography (hexane/EtOAc:20/1 $\rightarrow$ hexane/EtOAc:5/1), to provide 2MNS-5 $(29 \mathrm{mg}, 60 \%)$ as a colorless oil. $[\alpha]_{\mathrm{D}}{ }^{25}=+120.83\left(\mathrm{c}=0.11 \mathrm{in} \mathrm{CHCl}_{3}\right)$; $\mathrm{IR}\left(\right.$ neat, $\left.\mathrm{cm}^{-1}\right)$ : 3440, 3132, 2454, 1660, 1638, 1616, 1454, 1400, 1283, 1259, 1138, 1120, 1069, 999, 954, 864, 817, 716, 619, 564, 537, 517; ${ }^{1} \mathrm{H}-\mathrm{NMR}\left(\mathrm{CDCl}_{3}\right) \delta 5.46(\mathrm{~d}, J=4.1 \mathrm{~Hz}, 1 \mathrm{H}), 5.04(\mathrm{t}, J=3.9 \mathrm{~Hz}, 1 \mathrm{H}), 4.74(\mathrm{dd}, J=5.8$, $3.6 \mathrm{~Hz}, 1 \mathrm{H}), 4.63(\mathrm{t}, J=5.6 \mathrm{~Hz}, 1 \mathrm{H}), 4.30-4.19(\mathrm{~m}, 1 \mathrm{H}), 3.99(\mathrm{dd}, J=9.4,5.8 \mathrm{~Hz}, 1 \mathrm{H}), 3.81-3.71(\mathrm{~m}, 1 \mathrm{H})$, $3.63(\mathrm{dd}, J=9.4,7.0 \mathrm{~Hz}, 1 \mathrm{H}), 3.49-3.38(\mathrm{~m}, 1 \mathrm{H}), 2.41(\mathrm{~d}, J=8.0 \mathrm{~Hz}, 1 \mathrm{H}), 1.61-1.47(\mathrm{~m}, 2 \mathrm{H}), 1.41-1.28$ $(\mathrm{m}, 2 \mathrm{H}), 0.90(\mathrm{t}, J=7.3 \mathrm{~Hz}, 3 \mathrm{H}) .{ }^{13} \mathrm{C}-\mathrm{NMR}\left(\mathrm{CDCl}_{3}\right) \delta 102.6,85.9,82.6,78.2,72.0,70.9,68.7,31.3,19.1$, 13.7. HR-ESIMS $m / z[\mathrm{M}+\mathrm{H}]^{+}$: calcd for $\mathrm{C}_{10} \mathrm{H}_{18} \mathrm{NO}_{7}$ : 264.1005; found: 264.1010 . 
In a similar manner, 2MNS-6 (78 mg, 60\%) was obtained as a colorless oil from 2MNS-4 (150 mg, $0.49 \mathrm{mmol})$. $[\alpha]_{\mathrm{D}}{ }^{25}=-4.10\left(\mathrm{c}=0.12\right.$ in $\left.\mathrm{CHCl}_{3}\right)$; IR (neat, $\left.\mathrm{cm}^{-1}\right): 3440,3132,1655,1616,1454,1400,1305$, 1271, 1137, 1120, 1069, 995, 954, 860, 618, 564, 537, 517, 447; ${ }^{1} \mathrm{H}-\mathrm{NMR}\left(\mathrm{CDCl}_{3}\right) \delta 5.26(\mathrm{~s}, 1 \mathrm{H}), 5.20(\mathrm{~s}, 1 \mathrm{H})$, $4.85(\mathrm{t}, J=5.8 \mathrm{~Hz}, 1 \mathrm{H}), 4.56(\mathrm{~d}, J=5.6 \mathrm{~Hz}, 1 \mathrm{H}), 4.31-4.18(\mathrm{~m}, 1 \mathrm{H}), 3.95-3.87(\mathrm{~m}, 1 \mathrm{H}), 3.87-3.76(\mathrm{~m}, 2 \mathrm{H})$, 3.64-3.50 (m, 1H), $2.72(\mathrm{~d}, J=10.3 \mathrm{~Hz}, 1 \mathrm{H}), 1.80-1.50(\mathrm{~m}, 2 \mathrm{H}), 1.45-1.35(\mathrm{~m}, 2 \mathrm{H}), 0.94(\mathrm{t}, J=7.3 \mathrm{~Hz}, 3 \mathrm{H})$. ${ }^{13} \mathrm{C}-\mathrm{NMR}\left(\mathrm{CDCl}_{3}\right) \delta 107.1,89.6,84.4,83.4,73.5,71.2,69.8,31.4,19.2,13.8$. HR-ESIMS $m / z[\mathrm{M}+\mathrm{H}]^{+}$: calcd for $\mathrm{C}_{10} \mathrm{H}_{18} \mathrm{NO}_{7}$ : 264.1005; found: 264.1008 .

4.2.11. Synthesis of Butyl 3,6-anhydro-5-O-(3-nitro-4-methoxybenzyl)-2-O-nitro- $\alpha$-D-glucofuranoside (2MNS-7) and Butyl 3,6-anhydro-5-O-(4-methoxybenzyl)-2-O-nitro- $\beta$-D-glucofuranoside (2MNS-8)

Fuming nitric acid $(0.5 \mathrm{~mL})$ was added to acetic anhydride $(2 \mathrm{~mL})$ at $0{ }^{\circ} \mathrm{C}$. After stirring for $10 \mathrm{~min}$, the solution of $11 \mathrm{a}(200 \mathrm{mg}, 0.59 \mathrm{mmol})$ in $\mathrm{Ac}_{2} \mathrm{O}(2 \mathrm{~mL})$ was added into the acetic anhydride solution of fuming nitric acid. The mixture was stirred at $0{ }^{\circ} \mathrm{C}$ for $15 \mathrm{~min}$ and then poured into ice-water and extracted with EtOAc. The organic layer was washed with brine, dried with $\mathrm{Na}_{2} \mathrm{SO}_{4}$ and then concentrated under reduced pressure to give a crude product, which on column chromatography (hexane/EtOAc:20:1) gave 2MNS-7 $(205 \mathrm{mg}, 81 \%)$ as a colorless oil. $[\alpha]_{\mathrm{D}}{ }^{25}=+51.67(\mathrm{c}=0.13$ in $\mathrm{CHCl}_{3}$ ); IR (neat, $\mathrm{cm}^{-1}$ ):3440, 3132, 1640, 1616, 1534, 1454, 1400, 1282, 1138, 1070, 1017, 955, 863, 824, 623, 564, 537, 517. ${ }^{1} \mathrm{H}-\mathrm{NMR}\left(\mathrm{CDCl}_{3}\right) \delta 7.89(\mathrm{~d}, J=2.2 \mathrm{~Hz}, 1 \mathrm{H}), 7.56(\mathrm{dd}, J=8.6,2.2 \mathrm{~Hz}, 1 \mathrm{H}), 7.09$ $(\mathrm{d}, J=8.6 \mathrm{~Hz}, 1 \mathrm{H}), 5.46(\mathrm{~d}, J=4.2 \mathrm{~Hz}, 1 \mathrm{H}), 5.04(\mathrm{t}, J=3.7 \mathrm{~Hz}, 1 \mathrm{H}), 4.78-4.72(\mathrm{~m}, 1 \mathrm{H}), 4.72-4.62(\mathrm{~m}, 2 \mathrm{H})$, $4.57(\mathrm{~d}, J=11.8 \mathrm{~Hz}, 1 \mathrm{H}), 4.09-3.92(\mathrm{~m}, 5 \mathrm{H}), 3.82-3.62(\mathrm{~m}, 2 \mathrm{H}), 3.51-3.37(\mathrm{~m}, 1 \mathrm{H}), 1.60-1.46(\mathrm{~m}, 2 \mathrm{H})$, 1.40-1.26 (m, 2H), $0.90(\mathrm{t}, J=7.3 \mathrm{~Hz}, 3 \mathrm{H}) .{ }^{13} \mathrm{C}-\mathrm{NMR}\left(\mathrm{CDCl}_{3}\right) \delta 134.0,125.7,114.0,102.7,86.5,83.5,78.4$, 77.1, 71.6, 69.0, 69.0, 57.0, 31.7, 19.5, 14.1. HR-ESIMS $m / z[\mathrm{M}+\mathrm{H}]^{+}$: calcd for $\mathrm{C}_{18} \mathrm{H}_{24} \mathrm{~N}_{2} \mathrm{O}_{10}: 429.1431$; found: 429.1435 .

In a similar manner, 2MNS-8 (205 mg, 81\%) was obtained as a colorless oil from $\mathbf{1 1 b}(200 \mathrm{mg}$, $0.59 \mathrm{mmol}) \cdot[\alpha]_{\mathrm{D}}^{25}=+20.89\left(\mathrm{c}=0.14 \mathrm{in}^{\left.25 \mathrm{CCl}_{3}\right)}\right.$; IR (neat, $\left.\mathrm{cm}^{-1}\right): 3442,3132,1743,1649,1621,1534,1461$, $1400,1302,1269,1138,1119,1071,954,861,615,564,537,517 .{ }^{1} \mathrm{H}-\mathrm{NMR}\left(\mathrm{CDCl}_{3}\right) \delta 7.89(\mathrm{~d}, J=2.2 \mathrm{~Hz}$, $1 \mathrm{H}), 7.54(\mathrm{dd}, J=8.6,2.3 \mathrm{~Hz}, 1 \mathrm{H}), 7.08(\mathrm{~d}, J=8.6 \mathrm{~Hz}, 1 \mathrm{H}), 5.24(\mathrm{~s}, 1 \mathrm{H}), 5.17(\mathrm{~s}, 1 \mathrm{H}), 4.85(\mathrm{t}, J=5.0 \mathrm{~Hz}$, $1 \mathrm{H}), 4.72(\mathrm{~d}, J=11.4 \mathrm{~Hz}, 1 \mathrm{H}), 4.64(\mathrm{~d}, J=5.1 \mathrm{~Hz}, 1 \mathrm{H}), 4.52(\mathrm{~d}, J=11.4 \mathrm{~Hz}, 1 \mathrm{H}), 4.14-3.88(\mathrm{~m}, 6 \mathrm{H})$, 3.89-3.79 (m, 1H), 3.49-3.37 (m, 1H), 1.65-1.48 (m, 2H), 1.40-1.28 (m, 2H), $0.88(\mathrm{t}, J=7.3 \mathrm{~Hz}, 3 \mathrm{H})$. ${ }^{13} \mathrm{C}-\mathrm{NMR}\left(\mathrm{CDCl}_{3}\right) \delta 133.4,130.2,125.2,113.5,105.9,90.00,83.8,81.5,78.8,70.6,69.5,68.4,56.7,31.2$, 19.3, 13.8. HR-ESIMS $m / z[\mathrm{M}+\mathrm{H}]^{+}$: calcd for $\mathrm{C}_{18} \mathrm{H}_{24} \mathrm{~N}_{2} \mathrm{O}_{10}$ : 429.1431; found: 429.1428 .

4.2.12. Synthesis of Butyl 3,6-anhydro-2,5-di-O-nitro- $\alpha$-D-arabinohexofuranoside (DNS-1) and Butyl 3,6-anhydro-2,5-di-O-nitro- $\beta$-D-arabinohexofuranoside (DNS-2)

Fuming nitric acid $(0.5 \mathrm{~mL})$ was added to acetic anhydride $(2 \mathrm{~mL})$ at $0{ }^{\circ} \mathrm{C}$. After stirring for $10 \mathrm{~min}$, the solution of 12a (100 mg, $0.46 \mathrm{mmol})$ in $\mathrm{Ac}_{2} \mathrm{O}(2 \mathrm{~mL})$ was added into the acetic anhydride solution of fuming nitric acid. The mixture was stirred at $0{ }^{\circ} \mathrm{C}$ for $15 \mathrm{~min}$ and then poured into ice-water and extracted with EtOAc. The organic layer was washed with brine, dried with $\mathrm{Na}_{2} \mathrm{SO}_{4}$ and then concentrated under reduced pressure to give a crude product, which on column chromatography (hexane/EtOAc:20:1) gave DNS-1 $(113 \mathrm{mg}, 80 \%)$ as a colorless oil. $[\alpha]_{\mathrm{D}}^{25}=+140.45\left(\mathrm{c}=0.18 \mathrm{in}_{\mathrm{CHCl}}\right)$; IR (neat, $\mathrm{cm}^{-1}$ ): 3455, 3160, 1626, 1400, 1304, 1286, 1152, 1085, 1005, 985, 869, 844, 531; ${ }^{1} \mathrm{H}-\mathrm{NMR}\left(\mathrm{CDCl}_{3}\right)$ $\delta 5.44(\mathrm{~d}, J=4.0 \mathrm{~Hz}, 1 \mathrm{H}), 5.28(\mathrm{q}, J=5.6 \mathrm{~Hz}, 1 \mathrm{H}), 5.08(\mathrm{t}, J=3.9 \mathrm{~Hz}, 1 \mathrm{H}), 4.93(\mathrm{t}, J=5.6 \mathrm{~Hz}, 1 \mathrm{H}), 4.81$ $(\mathrm{dd}, J=5.9,3.7 \mathrm{~Hz}, 1 \mathrm{H}), 4.14(\mathrm{dd}, J=10.4,5.9 \mathrm{~Hz}, 1 \mathrm{H}), 3.98(\mathrm{dd}, J=10.4,5.6 \mathrm{~Hz}, 1 \mathrm{H}), 3.80-3.68(\mathrm{~m}, 1 \mathrm{H})$, 3.47-3.36 (m, 1H), 1.60-1.47 (m, 2H), 1.39-1.29 (m, 2H), $0.90(\mathrm{t}, J=7.3 \mathrm{~Hz}, 3 \mathrm{H}) .{ }^{13} \mathrm{C}-\mathrm{NMR}\left(\mathrm{CDCl}_{3}\right) \delta$ 103.2, 84.7, 83.2, 79.1, 77.5, 68.9, 68.2, 31.3, 19.1, 13.7. HR-ESIMS $m / z[\mathrm{M}+\mathrm{H}]^{+}$: calcd for $\mathrm{C}_{10} \mathrm{H}_{17} \mathrm{~N}_{2} \mathrm{O}_{9}$ : 309.0858; found: 309.0856 .

In a similar manner, DNS-2 (107 $\mathrm{mg}, 76 \%)$ was obtained as a colorless oil from $\mathbf{1 2 b}(100 \mathrm{mg}$, $0.46 \mathrm{mmol})$. $[\alpha]_{\mathrm{D}}{ }^{25}=+57.22\left(\mathrm{c}=0.12\right.$ in $\left.\mathrm{CHCl}_{3}\right)$; IR (neat, $\left.\mathrm{cm}^{-1}\right)$ : 3448, 3133, 1648, 1457, 1400, 1303, $1283,1121,1071,998,952,860,564,537,516 ;{ }^{1} \mathrm{H}-\mathrm{NMR}\left(\mathrm{CDCl}_{3}\right) \delta 5.29-5.17(\mathrm{~m}, 2 \mathrm{H}), 5.17-4.98(\mathrm{~m}, 2 \mathrm{H})$, $4.72(\mathrm{~d}, J=5.6 \mathrm{~Hz}, 1 \mathrm{H}), 4.21-4.06(\mathrm{~m}, 2 \mathrm{H}), 3.92-3.81(\mathrm{~m}, 1 \mathrm{H}), 3.50-3.38(\mathrm{~m}, 1 \mathrm{H}), 1.67-1.53(\mathrm{~m}, 2 \mathrm{H})$, 
1.45-1.34 (m, 2H), $0.94(\mathrm{t}, J=7.3 \mathrm{~Hz}, 3 \mathrm{H}) .{ }^{13} \mathrm{C}-\mathrm{NMR}\left(\mathrm{CDCl}_{3}\right) \delta$ 106.3, 89.6, 84.5, 81.3, 79.5, 68.9, 67.5, 31.2, 19.3, 13.9. HR-ESIMS $m / z$ [M + H] $]^{+}$: calcd for $\mathrm{C}_{10} \mathrm{H}_{17} \mathrm{~N}_{2} \mathrm{O}_{9}$ : 309.0856; found: 309.0856.

\subsection{Biology Evaluation}

\subsubsection{Nitric Oxide Releasing Assay}

NO has a short half-life, therefore, the quantification of NO metabolites like nitrite and nitrate is a useful method to quantify this molecule in the medium. The amount of NO released was indirectly detected by Griess reaction through the measurement of nitrites in the medium [33-35]. The solution of each nitrate derivative was prepared to $0.01 \mathrm{M} .0 .1 \mathrm{~mL}$ of the solution of nitrate derivative was added into the incubator, and volume to $10 \mathrm{~mL}$ with $5 \mathrm{mM} \mathrm{L}$-cysteine in phosphate buffer (pH 7.4). $150 \mu \mathrm{L}$ of mixture was pipetted into reaction tube after $0 \mathrm{~h}, 4 \mathrm{~h}, 8 \mathrm{~h}, 16 \mathrm{~h}, 20 \mathrm{~h}, 24 \mathrm{~h}, 28 \mathrm{~h}, 32 \mathrm{~h}$ of incubation at $37^{\circ} \mathrm{C}$. Then $50 \mu \mathrm{L}$ of the Griess reagent ( $4 \mathrm{~g}$ of sulfanilamide, $0.2 \mathrm{~g}$ of $\mathrm{N}$-naphthyl-ethylenediamine dihydrochloride, $85 \%$ phosphoric acid $(10 \mathrm{~mL}$ ) in distilled water (final volume, $100 \mathrm{~mL}$ )) was added into above reaction tube. After $10 \mathrm{~min}$ at room temperature, the absorbance was measured at $540 \mathrm{~nm}$. Standard sodium nitrite solutions $(0.15$ to $1.5 \mathrm{mg} / \mathrm{L})$ were used to construct the calibration curve. No production of nitrite was observed in the absence of L-cysteine. The yields of nitrite are expressed as $\mathrm{NO}_{2}{ }^{-}(\mu \mathrm{M})$. The experiments were performed in sextuplicate in three independent experiments. Data are expressed as the mean $\pm \mathrm{SD}$.

\subsubsection{Vasodilatory Potential on Isolated Rat Mesenteric Arterial Rings}

Adult male Sprague-Dawley rats (200-300 g, 2 months of age) were obtained from Experimental Animal Center of Shanghai Institute of Materia Medica (Shanghai, China). Male rats that had typical 4-day estrous cycles were used in the present study. Experimental animals, which were housed in a group of 4 per wire cage, were kept under standard laboratory conditions (12 h of light, $12 \mathrm{~h}$ of dark; $30^{\circ} \mathrm{C}$ ) for a week to acclimatize to laboratory conditions. During acclimatization, animals were provided food and water ad libitum. Vaginal smears were checked twice-daily ( 9 a.m. and 8 p.m.) to characterize the estrous cycle.

After rats were euthanized by cervical dislocation, the gastrointestinal tract with the mesenteric arcade attached was excised rapidly and kept in ice-cold physiological salt solution (PSS) with the following composition (mmol/L): $\mathrm{NaCl} 130, \mathrm{KCl} 4.7, \mathrm{MgSO}_{4}$ 1.17, $\mathrm{KH}_{2} \mathrm{PO}_{4} 1.18, \mathrm{NaHCO}_{3}$ 14.9, glucose 5.5 , and ethylene diamine tetraacetic acid 0.026. Second-order mesenteric small arteries $(<400 \mu \mathrm{M}$ internal diameter) were dissected and cleaned of adjoining fat and connective tissues [49].

The isolated mesenteric arteries of male Sprague-Dawley rats (200-300 g) were cut into ring segments of 3-4 $\mathrm{mm}$ in length. Each segment was mounted in a Powerlab isolated tissue perfusion system (AD Instruments, Dunedin, New Zealand) and the contractile responses were determined. The organ chamber was filled with $\mathrm{K}-\mathrm{H}$ solution, which was constantly bubbled with $95 \% \mathrm{O}_{2} / 5 \% \mathrm{CO}_{2}$ and maintained at $37^{\circ} \mathrm{C}$. After an equilibration period of $60 \mathrm{~min}$, the endothelial integrity was confirmed by acetylcholine (Ach, $1 \mu \mathrm{M})$-induced relaxation of phenylephrine $(1 \mu \mathrm{M})$ precontracted tissues. A relaxation rate $>70 \%$ of the phenylephrine-induced contraction was considered representative of an acceptable presence of the endothelial layer, while the organs, showing a relaxation rate $<70 \%$, were not used in the experimental procedures [50]. 30 to $40 \mathrm{~min}$ after the confirmation of the endothelial integrity, all rings were used in next experiences. The vascular preparation was normalized to the optimal initial tension at $0.5 \mathrm{~g}$ in accordance with the system instructions. All rings were allowed to stabilize at this baseline tone for $60 \mathrm{~min}$ before the start of each experiment.

The vasodilatory effect was reflected by the change of tension of isolated rat mesenteric arterial ring. The contraction that induced by $1 \mu \mathrm{M}$ phenylephrine or $60 \mathrm{mM} \mathrm{KCl}$ was indentified as standard contraction. The relaxation rate of each nitrate derivative was used as the effect that nitrate derivative on isolated rat mesenteric arterial ring. Relaxation rate $(\%)=(1-$ average minimum tension/average initial tension) $\times 100 \%$. The higher relaxation rate, the more potent vasodilatory effect. All the 
experiments were performed in triplicate in three independent experiments. Data are expressed as the mean \pm SD.

Mesenteric artery rings pre-contracted with $1 \mu \mathrm{M}$ phenylephrine. After a sustained contraction was obtained, nitrate derivative was added to the bathing solution at final concentration of $30 \mu \mathrm{M}$ to obtain preliminary vasdilatory effect.

Mesenteric artery rings pre-contracted with $1 \mu \mathrm{M}$ phenylephrine. After a sustained contraction was obtained, nitrate derivative was added to the bathing solution in a cumulative manner $(0,1,3,5$, $10,15,20,25,30,40,50,60,70 \mu \mathrm{M})$ to obtain concentration-response curves. Each concentration was applied for $5 \mathrm{~min}$ before addition of the next concentration. DMSO was used as a control to ensure a genuine relaxant effect of nitrate derivative. Dose response curve was plotted using the GraphPad Prism 5.0 software (GraphPad Software, Inc., San Diego, CA, USA).

Mesenteric artery rings pre-contracted with $60 \mathrm{mM} \mathrm{KCl}$. After a sustained contraction was obtained, nitrate derivative was added to the bathing solution at final concentration of $30 \mu \mathrm{M}$ to obtain preliminary vasdilatory effect.

Mesenteric artery rings pre-contracted with $60 \mathrm{mM} \mathrm{KCl}$. After a sustained contraction was obtained, nitrate derivative was added to the bathing solution in a cumulative manner $(0,1,3,5,10,15$, $20,25,30,40,50,60,70 \mu \mathrm{M})$ to obtain concentration-response curves. Each concentration was applied for $5 \mathrm{~min}$ before addition of the next concentration. DMSO was used as a control to ensure a genuine relaxant effect of nitrate derivative. Dose response curve was plotted using the GraphPad software.

\subsubsection{Effects of ODQ and PITO on Vasodilatory Effects of DNS-2}

Mesenteric artery rings were contracted by $1 \mu \mathrm{M}$ phenylephrine. After a sustained contraction was obtained, three groups of contracted rings were treated with PTIO $(100 \mu \mathrm{M})$, ODQ $(10 \mu \mathrm{M})$ and DNS-2, respectively. Other two groups of contracted rings were pretreated PTIO (100 $\mu \mathrm{M})$ or ODQ $(10 \mu \mathrm{M})$ for $15 \mathrm{~min}$, and then treated with DNS-2 (final concentration of $30 \mu \mathrm{M}$ ). ISDN instead of DNS-2 was in presence of positive control experience. Relaxation rate $(\%)=(1-$ average minimum tension/average initial tension) $\times 100 \%$. The experiments were performed in triplicate in three independent experiments. Data are expressed as the mean \pm SD.

\subsection{Statistical Analysis}

All the data were represented as mean \pm SD from triplicate experiments performed in a parallel manner unless otherwise indicated. Statistical analysis of comparisons between two groups was analyzed using an unpaired, two-tailed Student's $t$-test. Difference at the $p<0.05$ level was considered statistically significant.

\section{Conclusions}

In summary, a group of nitrate derivatives of naturally occurring sauropunol A and B were designed and synthesized. Biological evaluation of these compounds revealed that most of synthesized mononitrate derivatives demonstrated superior NO releasing capacity and vasodilatory effect than ISMN. Dinitrate DNS-2 presenting higher NO releasing capacity and vasodilatory effect than ISDN was found as the most ideal sauropunol-derived nitrate. High levels of NO and sGC may be essential for the potent vasodilatory effect of DNS-2. DNS-2 may display vasodilatory effects through cellular signal transduction of NO-sGC-cGMP. The above findings are believed to be not only important for the extension of potential pharmaceutical application of naturally occurring sauropunols, but also for identification of new NO-releasing agents with structurally diversified backbones. Based on these results, further SAR studies to develop new sauropunol-type vasodilatory agents with higher efficacy and safety profile is underway in our laboratory. 
Supplementary Materials: The following are available online, ${ }^{1} \mathrm{H}$ - and ${ }^{13} \mathrm{C}-\mathrm{NMR}$ spectra for all tatgeted compounds and 7a, 7b, 8, 9a, 9b. IR spectra for all tatgeted compounds and 8, 9a, 9b. Figure S1: The inhibitory effect of nitrates derivatives on the contraction induced by phenylephrine in mesenteric artery rings. Figure S2: The inhibitory effect of nitrates derivatives on the contraction induced by $\mathrm{KCl}$ in mesenteric artery rings.

Author Contributions: Conceptualization, X.W. and W.X.; Formal analysis, J.X., G.T., O.M., X.W. and W.X.; Investigation, L.L., X.R., R.C., C.Z., Z.W.; Methodology, L.L., X.R., R.C., C.Z., Z.W.; Project administration, W.X.; Supervision, W.X.; Writing—original draft, L.L. and W.X.; Writing—review \& editing, L.L. and W.X.

Funding: The authors declare no competing financial interest. This work was financially supported by the National Natural Science Foundation of China (Grant No. 81473081, 81673312), Natural Science Foundation of Jiangsu Province for outstanding young scholars (Grant No. BK20160078), Scientific Research Foundation for the Returned Overseas Chinese Scholars, Ministry of Education (2013) and Technology Foundation for Selected Overseas Chinese Scholar, Ministry of Personnel of China (2013).

Conflicts of Interest: The authors declare no conflict of interest.

\section{References}

1. Moncada, S. Nitric oxide: Discovery and impact on clinical medicine. J. R. Soc. Med. 1999, 92, $164-169$. [CrossRef] [PubMed]

2. Hutchinson, P.J.; Palmer, R.M.; Moncada, S. Comparative pharmacology of EDRF and nitric oxide on vascular strips. Eur. J. Pharmacol. 1987, 141, 445-451. [CrossRef]

3. Ignarro, L.J.; Buga, G.M.; Wood, K.S.; Byrns, R.E.; Chaudhuri, G. Endothelium-derived relaxing factor produced and released from artery and vein is nitric oxide. Proc. Nat. Acad. Sci. USA 1987, 84, 9265-9269. [CrossRef] [PubMed]

4. Pörsti, I.; Paakkari, I. Nitric oxide-based possibilities for pharmacotherapy. Ann. Med. 1995, 27, 407-420. [CrossRef]

5. Schuman, E.M.; Meffert, M.K.; Schulman, H.; Madison, D.V. An ADP-Ribosyltransferase as a Potential Target for Nitric Oxide Action in Hippocampal Long-Term Potentiation. Proc. Nat. Acad. Sci. USA 1994, 91, 11958-11962. [CrossRef] [PubMed]

6. Horton, A.; Nash, K.; Tackieyarboi, E.; Kostrevski, A.; Novak, A.; Raghavan, A.; Tulsulkar, J.; Alhadidi, Q.; Wamer, N.; Langenderfer, B. Furoxans (Oxadiazole-4N-oxides) with Attenuated Reactivity are Neuroprotective, Cross the Blood Brain Barrier, and Improve Passive Avoidance Memory. J. Med. Chem. 2018, 91, 4593-4607. [CrossRef] [PubMed]

7. Biava, M.; Battilocchio, C.; Poce, G.; Alfonso, S.; Consalvi, S.; Porretta, G.C.; Schenone, S.; Calderone, V.; Martelli, A.; Testai, L. Improving the solubility of a new class of antiinflammatory pharmacodynamic hybrids, that release nitric oxide and inhibit cycloxygenase-2 isoenzyme. Eur. J. Pharmacol. 2012, 58, 287-298. [CrossRef]

8. Kang, F.; Ai, Y.; Zhang, Y.; Huang, Z. Design and synthesis of new hybrids from 2-cyano-3,12-dioxooleana9-dien-28-oic acid and O2-(2,4-dinitrophenyl) diazeniumdiolate for intervention of drug-resistant lung cancer. Eur. J. Pharmacol. 2018, 149, 269-280.

9. Huang, Z.; Fu, J.; Zhang, Y. Nitric Oxide Donor-Based Cancer Therapy: Advances and Prospect. J. Med. Chem. 2017, 60, 7617-7635. [CrossRef]

10. Shami, P.J.; Saavedra, J.E.; Wang, L.Y.; Bonifant, C.L.; Diwan, B.A.; Singh, S.V.; Gu, Y.; Fox, S.D.; Buzard, G.S.; Citro, M.L. JS-K, a Glutathione/Glutathione S-Transferase-activated Nitric Oxide Donor of the Diazeniumdiolate Class with Potent Antineoplastic Activity1. Mol. Canc. Ther. 2003, 2, 409-417.

11. Huang, Z.; Wu, J.; Yu, Z.; Yuan, H.; Zhang, Y.; Yue, F.; Bhardwaj, A.; Kaur, J.; Knaus, E.E.; Zhang, Y. Glutathione S-Transferase $\pi$-Activatable $\mathrm{O}_{2}$-(Sulfonylethyl Derived) Diazeniumdiolates Potently Suppress Melanoma in Vitro and in Vivo. J. Med. Chem. 2018, 61, 1833-1844. [CrossRef] [PubMed]

12. Fernandes, G.F.D.S.; Souza, P.C.D.; Marino, L.B.; Chegaev, K.; Guglielmo, S.; Lazzarato, L.; Fruttero, R.; Chin, C.M.; Pavan, F.R.; Santos, J.L.D. Synthesis and biological activity of furoxan derivatives against Mycobacterium tuberculosis. Eur. J. Pharmacol. 2016, 123, 523-531. [CrossRef] [PubMed]

13. Long, R.; Jones, R.; Talbot, J.; Mayers, I.; Barrie, J.; Hoskinson, M.; Light, B. Inhaled Nitric Oxide Treatment of Patients with Pulmonary Tuberculosis Evidenced by Positive Sputum Smears. Antimicrob. Agents Chemother. 2005, 49, 1209-1212. [CrossRef] [PubMed] 
14. Regevshoshani, G.; Ko, M.; Miller, C.; Avgay, Y. Slow Release of Nitric Oxide from Charged Catheters and Its Effect on Biofilm Formation by Escherichia coli. Antimicrob. Agents Chemother. 2010, 54, 273-279. [CrossRef] [PubMed]

15. Robinson, J.L.; Brynildsen, M.P. A Kinetic Platform to Determine the Fate of Nitric Oxide in Escherichia coli. PLoS Comput. Biol. 2013, 9. [CrossRef] [PubMed]

16. Dos Santos, J.L.; Lanaro, C.; Lima, L.M.; Gambero, S.; Francopenteado, C.F.; Alexandremoreira, M.S.; Wade, M.; Yerigenahally, S.; Kutlar, A.; Meiler, S.E. Design, synthesis, and pharmacological evaluation of novel hybrid compounds to treat sickle cell disease symptoms. J. Med. Chem. 2011, 54, 5811-5819. [CrossRef] [PubMed]

17. Burgaud, J.L.; Riffaud, J.P.; Del, S.P. Nitric-oxide releasing molecules: D new class of drugs with several major indications. Curr. Pharm. Des. 2002, 8, 201-213. [CrossRef]

18. De Carvalho, P.S.; Maróstica, M.; Gambero, A.; Pedrazzoli, J., Jr. Synthesis and pharmacological characterization of a novel nitric oxide-releasing diclofenac derivative containing a benzofuroxan moiety. Eur. J. Med. Chem. 2010, 41, 2489-2493. [CrossRef]

19. Chen, J.; Wang, T.; Xu, S.; Lin, A.; Yao, H.; Xie, W.; Zhu, Z.; Xu, J. Design, synthesis and biological evaluation of novel nitric oxide-donating protoberberine derivatives as antitumor agents. Eur. J. Med. Chem. 2017, 132, 173-183. [CrossRef]

20. Bhandari, S.V.; Bothara, K.G.; Patil, A.A.; Chitre, T.S.; Sarkate, A.P.; Gore, S.T.; Dangre, S.C.; Khachane, C.V. Design, synthesis and pharmacological screening of novel antihypertensive agents using hybrid approach. Bioorg. Med. Chem. 2009, 17, 390-400. [CrossRef]

21. Burgaud, J.L.; Ongini, E.; Del, S.P. Nitric oxide-releasing drugs: A novel class of effective and safe therapeutic agents. Ann. N. Y. Acad. Sci. 2002, 962, 360-371. [CrossRef] [PubMed]

22. Françasilva, M.S.; Balarini, C.M.; Cruz, J.C.; Khan, B.A.; Rampelotto, P.H.; Braga, V.A. Organic nitrates: Past, present and future. Molecules 2014, 19, 15314-15323. [CrossRef] [PubMed]

23. Qiu, Q.; Zhen, H.S.; Wang, Y.; Jiang, J.G.; Yang, Y.Y. Studies on Acute Toxicity and Anti-inflammatory Effect of Root of Sauropus rostratus. Chin. J. Experim. Tradit. Med. Form. 2013, 19, 286-288. (In Chinese)

24. Huang, Y.; Tan, J.; Ma, W. Studies on antibacterial active of the extracts from Sauropus spatuli folius Beille in vitro. Pop. Sci. Technol. 2014, 2, 68-70. (In Chinese)

25. Zhen, H.S.; Liu, R.; Qiu, Q.; Jiang, J.G.; Yang, Y.Y. Anti-inflammatory and Analgesic Effect of Sauropus rostratus. Chin. J. Experim. Tradit. Med. Form. 2013, 19, 270-273. (In Chinese)

26. Subhasree, B.; Baskar, R.; Laxmi, K.R.; Lijina, S.R.; Rajasekaran, P. Evaluation of antioxidant potential in selected green leafy vegetables. Food Chem. 2009, 115, 1213-1220. [CrossRef]

27. Wang, C.; Li, W.; Liu, H.; Wang, J.; Li, G.; Wang, G.; Li, Y. Five natural carbohydrates from the leaves of Sauropus rostratus. Carbohydr. Res. 2014, 384, 99-101. [CrossRef]

28. Xie, W.; Lin, A.; Xu, J.; Wu, X. The Construction of Anhydro Monosaccharides. Asian J. Organic Chem. 2017, 6, 6-26. [CrossRef]

29. D'Alonzo, D.; De, F.M.; Porto, C.; Iacono, R.; Huebecker, M.; Cobucci-Ponzano, B.; Priestman, D.; Platt, F.M.; Parenti, G.; Moracci, M. N-Butyl-L-Deoxynojirimycin (L-NBDNJ): Synthesis of an Allosteric Enhancer of alpha-Glucosidase Activity for the Treatment of Pompe Disease. J. Med. Chem. 2017, 60, 9462-9469. [CrossRef]

30. Speciale, G.; FarrenDai, M.; Shidmoossavee, F.S.; Williams, S.J.; Bennet, A.J. C2-Oxyanion neighboring group participation: Transition state structure for the hydroxide-promoted hydrolysis of 4-nitrophenyl $\alpha$-D-mannopyranoside. J. Am. Chem. Soc. 2016, 138, 14012-14019. [CrossRef]

31. Liu, L.; Wang, C.Q.; Liu, D.; He, W.G.; Xu, J.Y.; Lin, A.J.; Yao, H.Q.; Tanabe, G.; Muraoka, O.; Xie, W.J. Construction of 3,6-Anhydrohexosides via Intramolecular Cyclization of Triflates and Its Application to the Synthesis of Natural Product Isolated from Leaves of Sauropus rostratus. Org. Lett. 2014, 16, 5004-5009. [CrossRef] [PubMed]

32. Zhang, C.; Wang, C.; Wang, Z.; Tanabe, G.; Muraoka, O.; Lin, A.; Xu, J.; Wu, X.; Wu, L.; Xie, W. Total synthesis, structural elucidation and anti-inflammatory activity evaluation of 2-deoxy-3,6-anhydro hexofuranoside derivatives isolated from Sauropus rostratus. Org. Biomol. Chem. 2016, 14, 10906-10913. [CrossRef] [PubMed]

33. Stoss, P.; Erhardt, E. Bicycloalkanol nitrates. Arch. Pharm. 1987, 320, 621-624. [CrossRef]

34. Shi, Z.D.; Yang, B.H.; Wu, Y.L. A stereospecific synthesis of 1 -deoxyribose, 1-ribose and l-ribosides. Tetrahedron 2002, 58, 3287-3296. [CrossRef] 
35. Barton, D.H.R.; Mccombie, S.W. A New Method for the Deoxygenation of Secondary Alcohols. J. Chem. Soc. 1975, 6, 553-559. [CrossRef]

36. Gurjar, M.K.; Patil, V.J.; Pawar, S.M. Synthesis of (1 R,5 R)-2,6-dioxabicyclo[3.3.0]octan-3-one from d -glucose. Carbohydrate Res. 1987, 165, 313-317. [CrossRef]

37. Bi, Y.; Yang, X.; Zhang, T.; Liu, Z.; Zhang, X.; Lu, J.; Cheng, K.; Xu, J.; Wang, H.; Lv, G. Design, synthesis, nitric oxide release and antibacterial evaluation of novel nitrated ocotillol-type derivatives. Eur. J. Med. Chem. 2015, 101, 71-80. [CrossRef]

38. Sorba, G.; Medana, C.; Fruttero, R.; Cena, C.; Stilo, A.D.; Ubaldina Galli, A.; Gasco, A. Water Soluble Furoxan Derivatives as NO Prodrugs. J. Med. Chem. 1997, 40, 463-469. [CrossRef]

39. Tsikas, D. Analysis of nitrite and nitrate in biological fluids by assays based on the Griess reaction: Appraisal of the Griess reaction in the L-arginine/nitric oxide area of research. J. Chromatogr. B Analyt. Technol. Biomed. Life Sci. 2007, 851, 51-70. [CrossRef]

40. Abrams, J. Mechanisms of action of the organic nitrates in the treatment of myocardial ischemia. Am. J. Cardiol. 1992, 70, B30-B42. [CrossRef]

41. Torfgård, K.E.; Ahlner, J. Mechanisms of action of nitrates. Cardiovasc. Drugs Ther. 1994, 8, 701-717. [CrossRef] [PubMed]

42. Liu, H.; Fu, S.; Hu, C.; Jia, C. Relaxing effect of an flavonoid WX-02 on isolated vascular rings of rabbits. J. Shen. Pharm. Univ. 2013, 9, 709-712. (In Chinese)

43. Heesen, B.J.; Hotchkiss, R.S.; Karl, I.E. Sepsis decreases phenylephrine- and KCl-induced aortic ring contraction and decreases the frequency of oscillations in active wall tension. Shock 1994, 2, 106-112. [CrossRef] [PubMed]

44. Goldstein, S.; Russo, A.; Samuni, A. Reactions of PTIO and carboxy-PTIO with *NO, *NO2, and O2-*. J. Biol. Chem. 2003, 278, 50949-50955. [CrossRef] [PubMed]

45. Wen, W.J.; Yong, W.J. Nitric oxide is involved in methyl jasmonate-induced defense responses and secondary metabolism activities of Taxus cells. Plant Cell Physiol. 2005, 46, 923-930.

46. Jian, W.W.; Li, P.Z.; Jian, Y.W.; Ren, X.T. Involvement of nitric oxide in oxidative burst, phenylalanine ammonia-lyase activation and Taxol production induced by low-energy ultrasound in Taxus yunnanensis cell suspension cultures. Nitric Oxide 2006, 15, 351-358.

47. Garthwaite, J.; Southam, E.; Boulton, C.L.; Nielsen, E.B.; Schmidt, K.; Mayer, B. Potent and selective inhibition of nitric oxide-sensitive guanylyl cyclase by $1 \mathrm{H}-[1,2,4]$ oxadiazolo[4,3-a]quinoxalin-1-one. Mol. Pharmacol. 1995, 48, 184-188.

48. Schrammel, A.; Behrends, S.; Schmidt, K.; Koesling, D.; Mayer, B. Characterization of 1H-[1,2,4]oxadiazolo [4,3-a]quinoxalin-1-one as a heme-site inhibitor of nitric oxide-sensitive guanylyl cyclase. Mol. Pharmacol. 1996, 50, 1-5.

49. Xu, W.Q.; Xiong, Z.Z.; Chen, T.T.; Gao, X.Y.; Yu, H.; Zhang, S.Q.; Cao, Y. X, Vasodilation effect of 2-benzyl-5-hydroxy-6-methoxy-3, 4-dihydroisoquinolin-1-one. Arch. Pharmacal. Res. 2012, 35, 1471-1477. [CrossRef]

50. Lubomirov, L.; Gagov, H.; Petkova-Kirova, P.; Duridanova, D.; Kalentchuk, V.U.; Schubert, R. Urocortin relaxes rat tail arteries by a PKA-mediated reduction of the sensitivity of the contractile apparatus for calcium. British J. Pharmacol. 2010, 134, 1564-1570. [CrossRef]

Sample Availability: Samples of the compounds are available from the authors. 